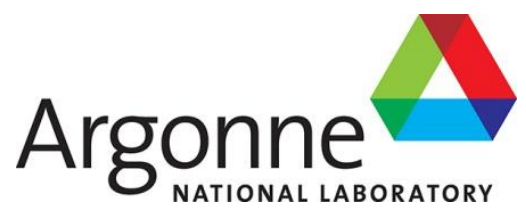

\title{
Steady-State Thermal-Hydraulics Analyses for the Conversion of the BR2 Reactor to LEU
}

Nuclear Engineering Division 
About Argonne National Laboratory

Argonne is managed by UChicago Argonne, LLC, for the

U.S. Department of Energy under contract DE-AC02-06CH11357. The

Laboratory's main facility is outside Chicago, at 9700 South Cass

Avenue, Argonne, Illinois 60439. For information about Argonne and its

pioneering science and technology programs, see www.anl.gov.

\section{DOCUMENT AVAILABILITY}

Online Access: U.S. Department of Energy (DOE) reports produced after 1991 and a

growing number of pre-1991 documents are available free via DOE's SciTech

Connect (http://www.osti.gov/scitech/)

Reports not in digital format may be purchased by the public from the

National Technical Information Service (NTIS):

U.S. Department of Commerce National

Technical Information Service 5301

Shawnee Rd

Alexandra, VA 22312

www.ntis.gov

Phone: (800) 553-NTIS (6847) or (703) 605-6000

Fax: (703) 605-6900

Email: orders@ntis.gov

Reports not in digital format are available to DOE and DOE contractors from the Office of Scientific and Technical Information (OSTI):

U.S. Department of Energy

Office of Scientific and Technical Information

P.O. Box 62

Oak Ridge, TN 37831-0062

www.osti.gov

Phone: (865) 576-8401

Fax: (865) 576-5728

Email: reports@osti.gov

\section{Disclaimer}

This report was prepared as an account of work sponsored by an agency of the United States Government. Neither the United States Government nor any agency thereof, nor UChicago Argonne, LLC, nor any of their employees or officers, makes any warranty, express or implied, or assumes any legal liability or responsibility for the accuracy, completeness, or usefulness of any information, apparatus, product, or process disclosed, or represents that its use would not infringe privately owned rights. Reference herein to any specific

commercial product, process, or service by trade name, trademark, manufacturer, or otherwise, does not necessarily constitute or imply its endorsement, recommendation, or favoring by the United States Government or any agency thereof. The views and opinions of document authors expressed herein do not necessarily state or reflect those of the United States Government or any agency thereof, Argonne National Laboratory, or UChicago Argonne, LLC. 
ANL/GTRI/TM-14/8

\section{Steady-State Thermal-Hydraulics Analyses for the Conversion of the BR2 Reactor to LEU}

prepared by

J.R. Licht ${ }^{1}$, A. Bergeron ${ }^{1}$ and B. Dionne ${ }^{1}$

${ }^{1}$ Nuclear Engineering Division, Argonne National Laboratory, Argonne, IL 60439

and

G. Van den Branden ${ }^{2}$, S. Kalcheva ${ }^{2}$, E. Sikik ${ }^{2}$ and E. Koonen ${ }^{2}$

${ }^{2}$ BR2 Reactor Department, SCK·CEN

December, 2015

This work is sponsored by the

U.S. Department of Energy, National Nuclear Safety Administration (NNSA),

Office of Material Management and Minimization (NA-23) Reactor Conversion Program 
(This page intentionally left blank) 


\section{Table of Contents}

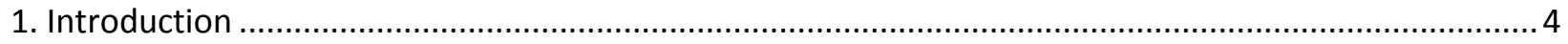

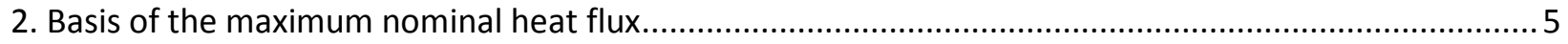

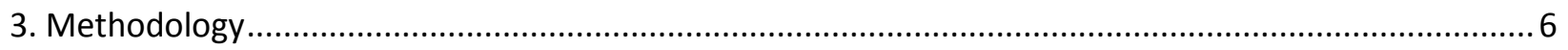

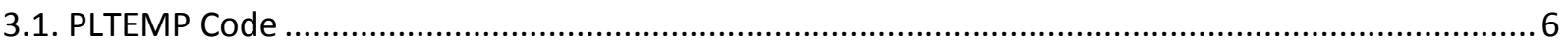

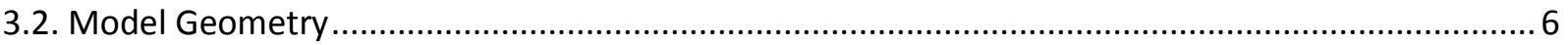

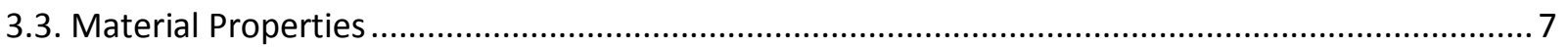

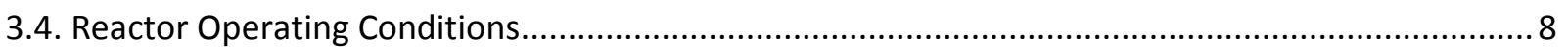

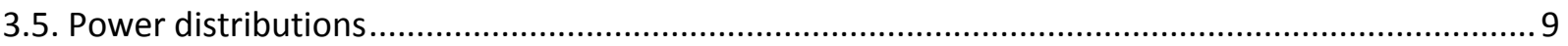

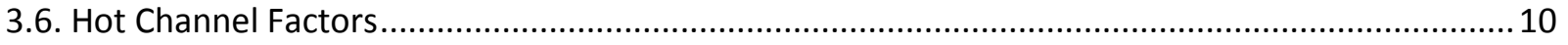

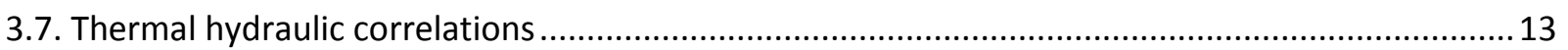

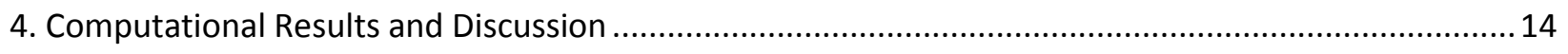

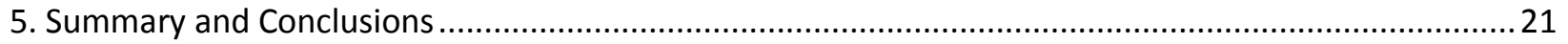

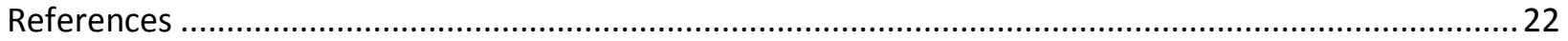

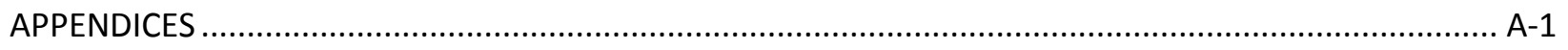

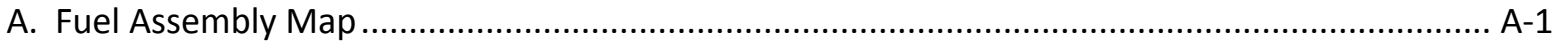

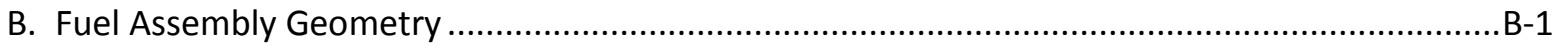

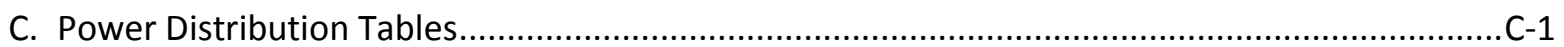

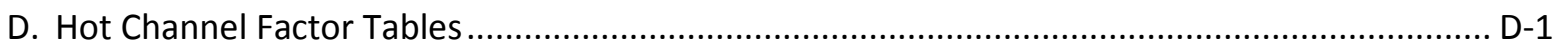

E. Evaluation of the Uncertainty on Flow Distribution ............................................................... E-1

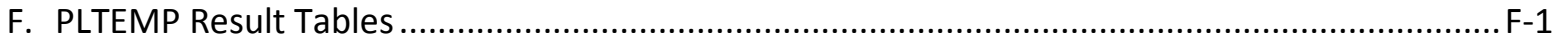

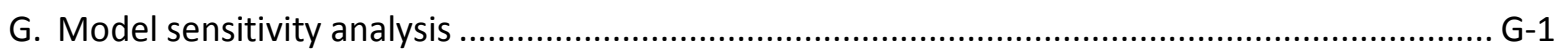




\section{Introduction}

BR2 is a research reactor used for radioisotope production and materials testing. It's a tank-in-pool type reactor cooled by light water and moderated by beryllium and light water (Figure 1). The reactor core consists of a beryllium moderator forming a matrix of 79 hexagonal prisms in a hyperboloid configuration; each having a central bore that can contain a variety of different components such as a fuel assembly, a control or regulating rod, an experimental device, or a beryllium or aluminum plug. Based on a series of tests, the BR2 operation is currently limited to a maximum allowable heat flux of $470 \mathrm{~W} / \mathrm{cm}^{2}$ to ensure fuel plate integrity during steadystate operation and after a loss-of-flow/lossof-pressure accident.

A feasibility study [1] for the conversion of the BR2 reactor from highly-enriched uranium (HEU) to low-enriched uranium (LEU) fuel was previously performed to verify it can operate safely at the same maximum nominal steady-state heat flux. An assessment was also performed to quantify the heat fluxes at which the onset

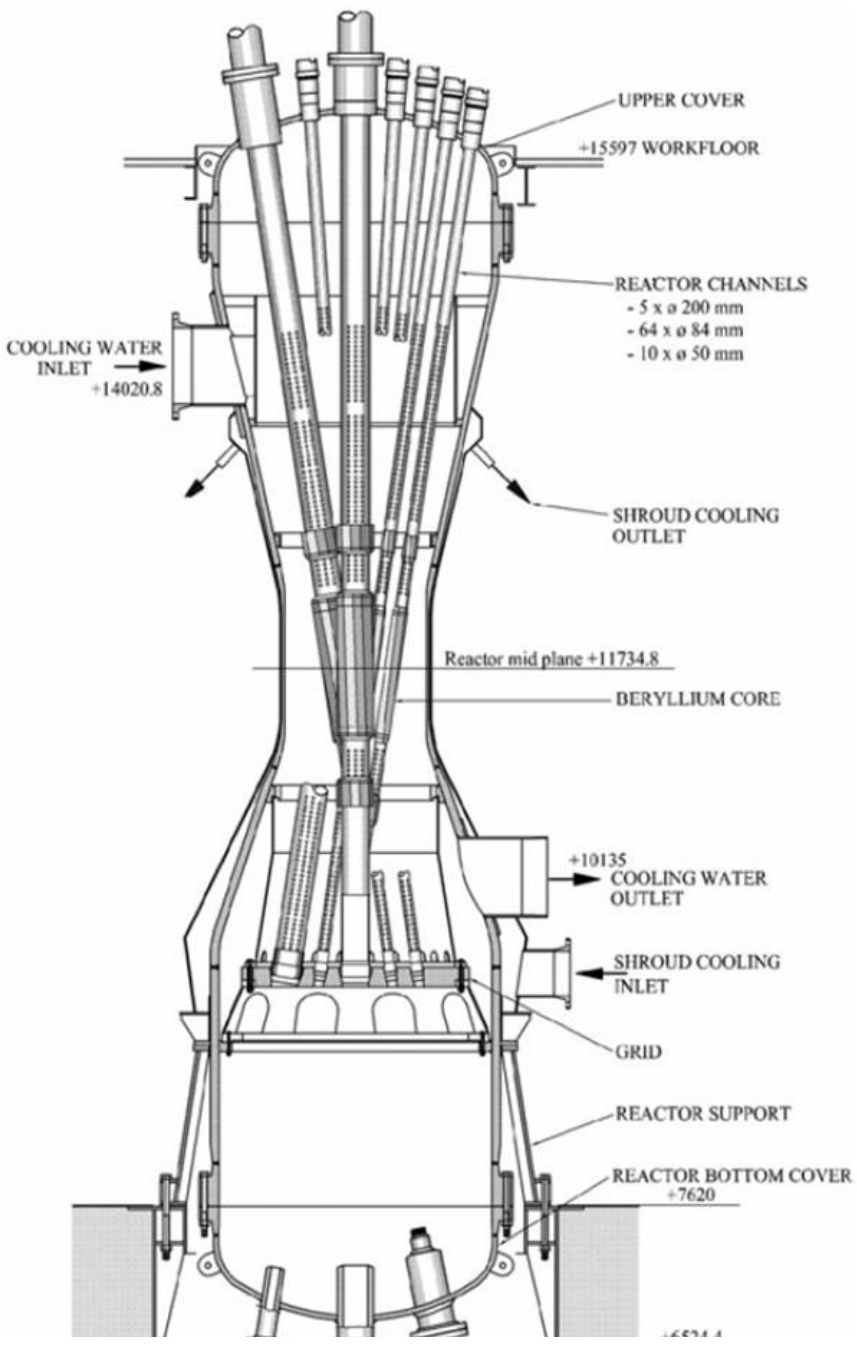

Figure 1. BR2 reactor schematic. of flow instability and critical heat flux occur for each fuel type [2]. This document updates and expands these results for the current representative core configuration (assuming a fresh beryllium matrix) by evaluating the onset of nucleate boiling (ONB), onset of fully developed nucleate boiling (FDNB), onset of flow instability (OFI) and critical heat flux (CHF). In addition, the highest heat flux assembly from each fuel cycle group (Appendix A), at beginning of cycle (BOC) conditions, was evaluated to determine the limiting assembly based on the above thermal hydraulic $(\mathrm{T}-\mathrm{H})$ criteria and the fuel centerline temperature. These fuel assemblies are characteristic of fresh fuel ( $0 \%$ burnup), the highest heat flux (16\% burnup), the highest power (32\% burnup, in central core position) and the highest burnup (46\% burnup). Calculation of the fuel centerline temperature has been added to this study due to the concern of significant degradation in fuel thermal conductivity that occurs with burnup for the proposed LEU fuel (uncoated U7Mo dispersed in Al). A model for oxide buildup at the cladding surface has also been incorporated to better simulate the fuel temperature. 
The second section describes the basis for the current thermal limits. The third section describes the key modeling assumptions and a description of the inputs incorporated into this work. The fourth section provides the updated $\mathrm{T}-\mathrm{H}$ results for the high heat flux fuel assembly. This section also includes comparisons of the $\mathrm{T}-\mathrm{H}$ criteria and fuel centerline temperature of the high heat flux fuel assembly relative to the fresh fuel, high power and high burnup assemblies.

\section{Basis of the maximum nominal heat flux}

The heat removal at BR2 must satisfy the requirement that the integrity of fuel plates is ensured during steady-state operation and after a Loss-Of-Flow/Loss-Of-Pressure (LOF/LOP) accident [3]. In order to maintain the integrity of the fuel, it is necessary to ensure that no flow-related problems such as flow instability (FI) and departure from nucleate boiling (DNB) can occur. Typically, this is accomplished by demonstrating that the power at which the selected safety criterion occurs exceeds the operating power with sufficient margins.

However, in the case of the BR2 core, using an allowed core power is not useful since it could vary for each possible core configuration (different numbers of fuel assemblies as well as different locations for the fuel assemblies and experimental devices) and loadings (fuel assemblies with different burnups). An allowed heat flux (referred to herein as the maximum nominal heat flux) is a more useful safety parameter since it can be analyzed independently of the core configuration and it can be related to the operating power for a given core configuration by a neutronics calculation.

For the BR2 core, this maximum nominal heat flux is defined, at steady-state, in relation to the occurrence of ONB. By preventing any form of boiling, i.e., by ensuring that the reactor is operated below ONB, it is impossible for OFI and DNB to occur. Historically, the BR2 steady-state thermal limits determined using the FABREGA code [4] showed that ONB, FDNB and OFI occurred at the following heat fluxes [5]:

- ONB occurred at $603 \mathrm{~W} / \mathrm{cm}^{2}$

- FDNB occurred at $675 \mathrm{~W} / \mathrm{cm}^{2}$

- OFI occurred at $709 \mathrm{~W} / \mathrm{cm}^{2}$

As mentioned above, the fuel integrity must also be maintained during a LOF/LOP accident. Therefore, based on the BR2 core thermal-hydraulic performance during a LOF/LOP accident, as tested in 1963, the maximum nominal heat flux was set to $430 \mathrm{~W} / \mathrm{cm}^{2}$ for routine operation (operating license Royal Decree N.0024 of June 30, 1986, article 4.11) in order to protect against boiling risk when flow inversion occurs during this transient. Since 1986, a permanent deviation for a heat flux up to $470 \mathrm{~W} / \mathrm{cm}^{2}$ is authorized (note GF/PGo/gd/86-783/F175 van 15 juli 1986). For a specific case, subject to an experimental demonstration (or a detailed analysis) that a total LOP event would not damage the fuel plates for this case, a maximum heat flux of $600 \mathrm{~W} / \mathrm{cm}^{2}$ can be temporarily allowed [6].

A preliminary comparison between the FABREGA and PLTEMP codes was performed and documented [7]. Learning from this experience, the current analysis refines and expands on this prior work. 


\section{Methodology}

\subsection{PLTEMP Code}

The code PLTEMP/ANL version 4.2 (May 18, 2015) [8] was used for all thermal hydraulic simulations to take advantage of the extended Groeneveld 2006 CHF lookup table (described in Section 3.7). The code will be referred to as PLTEMP from here on.

\subsection{Model Geometry}

A standard BR2 fuel assembly is composed of 18 fuel plates arranged into six concentric fuel "tubes" divided by aluminum stiffeners into three sectors (Figure 2). Each fuel plate consists of a fuel meat (UAl - Al for HEU, uncoated U7Mo dispersed in Al proposed for LEU) clad by aluminum (AG3NE). The PLTEMP model was based on a detailed description of the fuel assembly geometry given in Refs. [9], including fuel plate materials, dimensions such as radius of curvature, clad thickness, meat thickness, plate full and heat length, as well as coolant channel thickness and areas (Appendix B). The nominal dimensions are identical for each fuel type although the LEU fuel has cadmium wires in the aluminum stiffeners to improve neutronics.
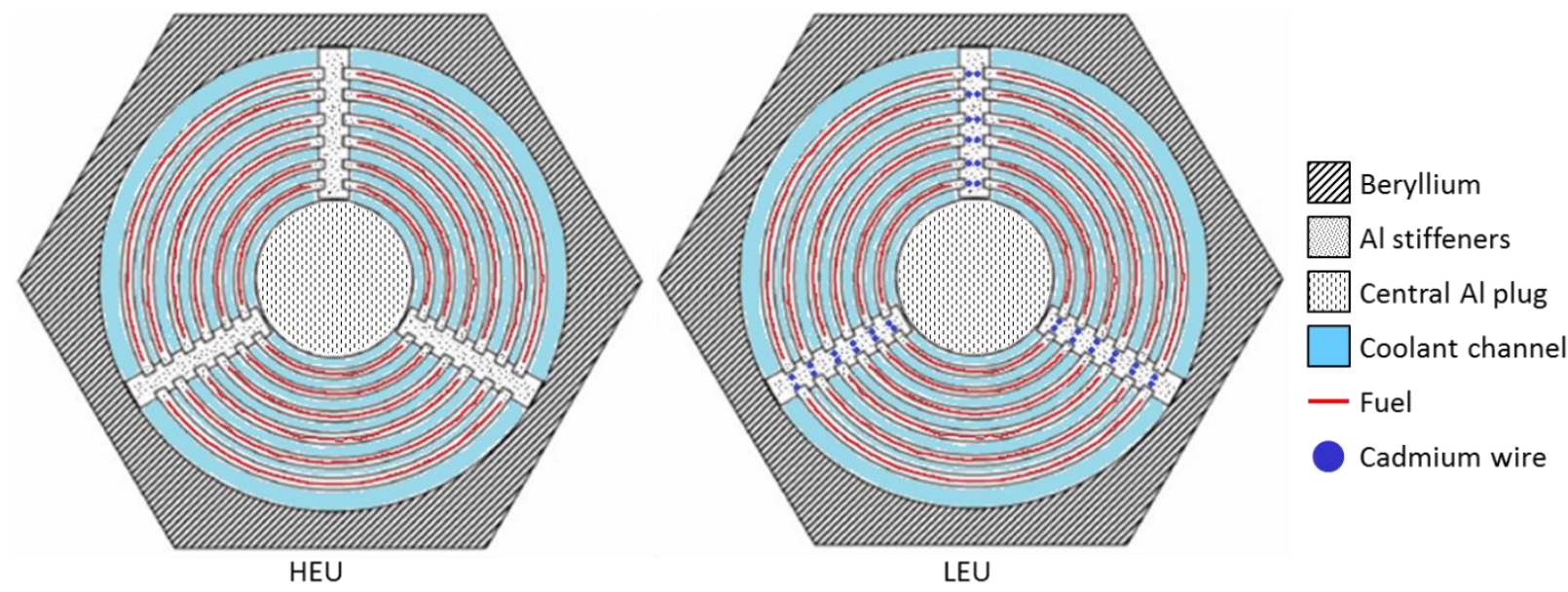

Figure 2. Cross-section of the current HEU and proposed LEU fuel assemblies.

A minor change from the previous work described in Refs. [1] and [2] is that only the limiting sector has been included in the PLTEMP model ${ }^{1}$. The limiting sector contains 6 fuel plates and 7 coolant channels thermally coupled in the radial direction. No heat conduction was modeled in the azimuthal and axial directions. The central plug, stiffeners and beryllium were modeled as adiabatic boundary conditions.

A more significant change from previous work is that the PLTEMP five-layer plate model has been used to enable specifying a thermal resistance due to oxide at the cladding/coolant interface. There were two consequences to using the five-layer plate model. First, it requires specifying the axial power shape for each plate. While the previous analyses only used the axial power shape for plate 6 (plate with highest heat flux), these analyses used the power shape calculated for each plate. Second, the five-layer

\footnotetext{
${ }^{1}$ This means that the second and third sectors have been removed from PLTEMP cards 309 and 310 . This has no impact on the results but simplifies the input model.
} 
plate model requires dividing the fuel assembly sector into three axial stripes. Thus, each plate contains three axial stripes, one stripe associated with the fuelled region and the other two associated with the unfueled regions at the azimuthal edges of the plate. This same stripe configuration was required for each of the coolant channels. Because there is no heat transfer between stripes, the enthalpy rise of the coolant in the fueled region does not take into account the coolant in the unfueled regions. Thus, an increase in conservatism should be expected with respect to results presented in Refs. [1] and [2]. A sensitivity analysis was performed to evaluate the impact of these changes (see Appendix G).

It is also necessary to model three axial regions of the fuel assembly and its enclosure. These were the unheated section at the assembly inlet, the heated section, and the unheated section at the outlet end of the assembly. The three regions used the same geometrical configuration.

\subsection{Material Properties}

The water properties are determined automatically by the PLTEMP code as required from temperature, pressure and enthalpy.

The specification for the thermal resistance (material properties and dimensions) of the HEU and LEU fuel plates was based on the analyses described in Ref. [10]. Briefly, it was assumed that a fuel element is shuffled to four locations (four burnup groups) throughout its lifecycle with an average BOC burnup value of $0 \%, 16 \%, 32 \%$ and $46 \%$ for each location. These fuel assemblies are characteristic of a fresh fuel assembly ( $0 \%$ burnup), the highest heat flux assembly within the reactor ( $16 \%$ burnup), the highest power assembly within the reactor (32\% burnup) and the highest burnup assembly within the reactor (46\% burnup). Within each burnup group there is a fuel element that operates at the highest heat flux (see Appendix A for a diagram). Although it is unlikely that a given fuel element will operate at the highest heat flux of each burnup group during its lifecycle, this was the case considered for these analyses. Thus, it is conservatively assumed that the fuel element used for this analysis was operated at the maximum heat flux during its lifecycle in each burnup group. Models described in Ref. [10] for HEU and LEU fuel were used to calculate the parameters important to the evolution of the thermal resistance of this fuel element. The HEU model contained factors such as porosity, fuel particle volume fraction and burnup. The LEU model was significantly more detailed and included factors such as swelling, porosity, interaction layer growth, matrix consumption, fuel temperature, heat flux and burnup. Both models included an equation to describe the oxide growth at the surface of the cladding. The results from Ref. [10] were incorporated into PLTEMP card 306B and are given here in Table 1 and Table 2. The cladding conductivity was assumed to be $130 \mathrm{~W} / \mathrm{m}-\mathrm{K}$.

Table 1. Plate parameters for the highest heat flux fuel assembly at each cycle (HEU fuel).

\begin{tabular}{|c|c|c|c|c|c|c|c|c|c|}
\hline Cycle & $\begin{array}{c}\text { Average } \\
\text { Burnup } \\
\%\end{array}$ & Description & $\begin{array}{c}\text { BR2 } \\
\text { Channel } \\
\text { Location }\end{array}$ & $\begin{array}{c}\text { Meat } \\
\text { thickness } \\
\mu \mathrm{m}\end{array}$ & $\begin{array}{c}\text { Clad } \\
\text { thickness } \\
\mu \mathrm{m}\end{array}$ & $\begin{array}{c}\text { Oxide } \\
\text { thickness } \\
\mu \mathrm{m}\end{array}$ & $\begin{array}{c}\text { Plate } \\
\text { thickness } \\
\mu \mathrm{m}\end{array}$ & $\begin{array}{c}\text { HEU Meat } \\
\text { conductivity } \\
\mathrm{W} / \mathrm{m}-\mathrm{K}\end{array}$ & $\begin{array}{c}\text { Oxide } \\
\text { resistance } \\
\mathrm{m}^{2}-\mathrm{K} / \mathrm{W}\end{array}$ \\
\hline $1^{\text {st }}$ & 0 & fresh fuel & C-259 & 508.0 & 381.0 & 0.0 & 1270.0 & 80.5 & 0 \\
\hline $2^{\text {nd }}$ & 16 & high heat flux & A-30 & 536.0 & 376.7 & 10.7 & 1310.8 & 64.1 & $4.8 \mathrm{e}-6$ \\
\hline $3^{\text {rd }}$ & 32 & high power & H1 & 561.2 & 375.2 & 14.4 & 1340.5 & 51.2 & $6.4 \mathrm{e}-6$ \\
\hline $4^{\text {th }}$ & 46 & high burnup & F-346 & 577.3 & 375.1 & 14.9 & 1357.2 & 43.9 & $6.6 \mathrm{e}-6$ \\
\hline
\end{tabular}


Table 2. Plate parameters for the high heat flux fuel assembly in each cycle (LEU fuel).

\begin{tabular}{|c|c|c|c|c|c|c|c|c|c|}
\hline Cycle & $\begin{array}{c}\text { Average } \\
\text { Burnup \% }\end{array}$ & Description & Location & $\begin{array}{c}\text { Meat } \\
\text { thickness } \\
\mu \mathrm{m}\end{array}$ & $\begin{array}{c}\text { Clad } \\
\text { thickness } \\
\mu \mathrm{m}\end{array}$ & $\begin{array}{c}\text { Oxide } \\
\text { thickness } \\
\mu \mathrm{m}\end{array}$ & $\begin{array}{c}\text { Plate } \\
\text { thickness } \\
\mu \mathrm{m}\end{array}$ & $\begin{array}{c}\text { LEU Meat } \\
\text { conductivity } \\
\mathrm{W} / \mathrm{m}-\mathrm{K}\end{array}$ & $\begin{array}{c}\text { Oxide } \\
\text { resistance } \\
\mathrm{m}^{2}-\mathrm{K} / \mathrm{W}\end{array}$ \\
\hline $1^{\text {st }}$ & 0 & fresh fuel & $\mathrm{C}-319$ & 508.0 & 381.0 & 0.0 & 1270.0 & 86.1 & 0 \\
\hline $2^{\text {nd }}$ & 16 & high heat flux & $\mathrm{A}-30$ & 536.0 & 376.5 & 11.3 & 1311.6 & 36.0 & $5.0 \mathrm{e}-6$ \\
\hline $3^{\text {rd }}$ & 32 & high power & $\mathrm{H} 1$ & 558.4 & 375.0 & 15.0 & 1338.5 & 23.5 & $6.7 \mathrm{e}-6$ \\
\hline $4^{\text {th }}$ & 46 & high burnup & $\mathrm{F}-346$ & 567.0 & 374.8 & 15.6 & 1347.7 & 19.4 & $6.9 \mathrm{e}-6$ \\
\hline
\end{tabular}

\subsection{Reactor Operating Conditions}

The inlet temperature for the PLTEMP model was assumed to be the same as pressure vessel inlet value $\left(40^{\circ} \mathrm{C}\right)$ and assumes the heat transferred to the coolant from the vessel and internal components is negligible. The inlet pressure was specified as $1.24 \mathrm{MPa}$ and was determined from the measured value with corrections for the static head, atmospheric pressure and instrument uncertainty.

In order to properly model the total pressure drop across the fuel plates, it was necessary to take into account the form loss factors due to change in geometry at the inlet and exit of the fuel assembly. The loss factors were set to match the PLTEMP pressure drop to the measured value of $2.1 \mathrm{~kg} / \mathrm{cm}^{2}$ (0.2059 MPa) [3]. The calibration was performed at $40{ }^{\circ} \mathrm{C}$ and $1.24 \mathrm{MPa}$ with an average coolant speed of $10.4 \mathrm{~m} / \mathrm{s}$ [11]. The calibration was assumed to hold for all operating conditions.

To perform the analysis at different mass flow rates (coolant speeds) it was necessary to evaluate the change in pressure drop across the fuel plates as a function of the mass flow rate. PLTEMP was used to evaluate this change in pressure drop (Figure 3) for cold conditions (0.1 MW).

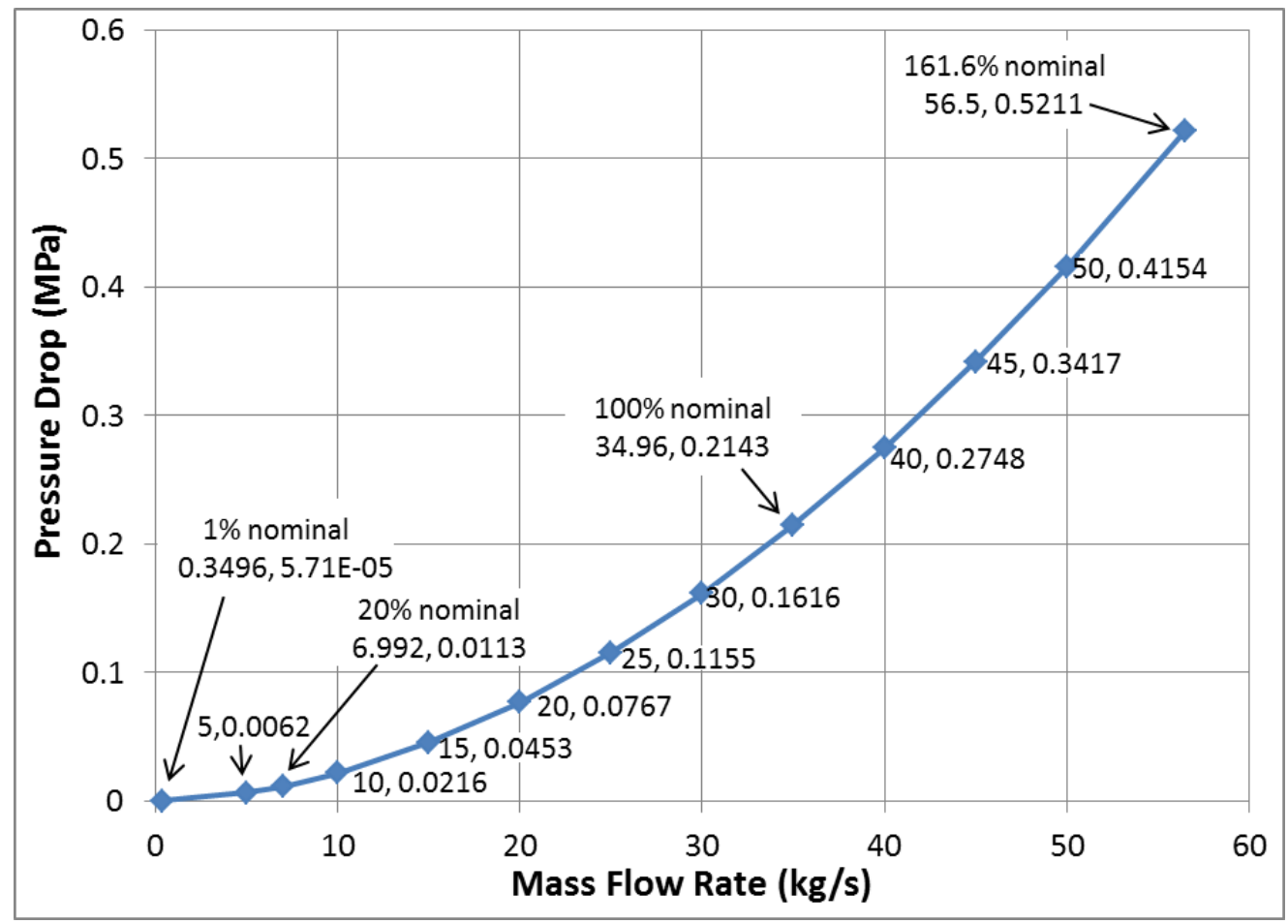

Figure 3 PLTEMP pressure drop versus mass flow rate in a BR2 fuel assembly. 


\subsection{Power distributions}

MCNP5 calculations were performed for the current representative core at BOC with both HEU and LEU fuel to obtain the power distribution inputs for PLTEMP (Appendix C). The MCNP5 model included 20 uniform axial nodes in the fuel region. For each axial node in the fourth, fifth and sixth plates, the azimuthal discretization included 9 non-uniform segments per sector to resolve the azimuthal power peaking for the higher heat flux plates; the remaining plates were not discretized in the azimuthal direction.

Three types of data were required for describing the power distribution of the limiting sector within the PLTEMP model:

1. FACTF $_{k}$ was defined as the average power density in a given plate (k) relative to the average power density of the sector.

2. $Q A V G_{k, n}$ was defined as the axial power density in each axial node ( $n$ ) normalized to 1 for each plate $(\mathrm{k})$ in the sector.

3. $F_{p}$ was defined as the azimuthal power peak-to-average ratio applied to all plates in the sector ${ }^{2}$. $F_{p}$ was calculated from the power density specified for each of the azimuthal segments of plate 6 (outer plate) at the axial location of the peak heat flux. This value was incorporated into the hot channel factors $F_{q}, F_{\text {bulk }}$ and $F_{\text {film }}$ described in Section 3.6.

The peak heat flux in plate $6, Q_{6}^{\prime \prime}$, can be reproduced from:

$$
Q_{6}^{\prime \prime}=\frac{P_{s} \cdot F A C T F_{6} \cdot V_{6} \cdot Q A V G_{6} \cdot F_{p}}{V_{S} \cdot S A_{6}}
$$

where $P_{S}$ is the sector power, $V_{6}$ is the volume of fuel in plate $6, V_{S}$ is the volume of fuel in the sector and $S A_{6}$ is the heated surface area of plate 6.

For the purposes of comparing the $\mathrm{T}-\mathrm{H}$ margins and peak fuel centerline temperature of fuel assemblies in different channels, the power from the limiting sector in the fresh fuel assembly (channel C-259 for HEU and C-319 for LEU), the high power assembly (channel $\mathrm{H}-1$ ) and the high burnup assembly (channel F-314) was specified relative to the power from the limiting sector in the high heat flux assembly (channel A-30). The values are given in Tables C-1 through C-4.

Finally, this analysis assumes that the fraction of the fission energy deposited in any structures other than the fuel meat (beryllium, aluminum, etc.) is deposited in the coolant in addition to the coolant

\footnotetext{
${ }^{2}$ Previous experience in analyzing the current BR2 core shows that the azimuthal power peak can be located at any angle along the arc length of a fuel plate based on its orientation with respect to the core centerline. Experience also shows that the magnitude of the peak is rather insensitive to the orientation or to the type of dispersed fuel meat. Therefore, the power peak is assumed to occur at the azimuthal center of the fuel plate where the lateral heat conduction is minimal. Under that assumption, the azimuthal power peak-to-average ratio can be used to model the heat flux distribution.
} 
direct heating. Table 3 provides the fission energy, calculated by MCNP5, that is assumed to be deposited directly in the coolant for each channel and fuel type. The remainder of the fission energy is conducted through the clad into the coolant. It should be noted that the amount of heat deposited in the coolant is lower for LEU fuel since it has a higher ${ }^{235} \mathrm{U}$ density (higher gamma heating fraction).

Table 3 Fission energy assumed to be deposited directly in the coolant.

\begin{tabular}{|c|c|c|}
\hline \multirow{2}{*}{ Fuel assembly (Channel) } & \multicolumn{2}{|c|}{$\%$ heat assumed deposited directly in the coolant } \\
\hline & HEU & LEU \\
\hline Fresh fuel (C-259 for HEU and C-319 for LEU) & 5.9 & 4.6 \\
\hline High heat flux (A-30, both HEU and LEU) & 5.6 & 3.7 \\
\hline High power (H-1, both HEU and LEU) & 3.7 & 3.0 \\
\hline High burnup (F-346. both HEU and LEU) & 5.6 & 3.6 \\
\hline
\end{tabular}

\subsection{Hot Channel Factors}

Hot channel factors (HCFs) are needed in order to account for fuel assembly manufacturing tolerances and various other uncertainties. Manufacturing tolerances are known for the HEU fuel currently in use at BR2. It is anticipated that manufacturing tolerances will be similar for LEU fuel since the fuel assembly and the fuel plate design are almost identical. Therefore, it is reasonable to assume that the uncertainties and manufacturing tolerances that apply to the HEU fuel assembly can be used for the LEU fuel assembly. The HCFs determined for HEU and LEU fuel include the heat flux HCF $\left(F_{\text {flux }}\right)$, heat transfer coefficient $\operatorname{HCF}\left(F_{h}\right)$, bulk temperature rise $\operatorname{HCF}\left(F_{\text {bulk }}\right)$ and film temperature rise $\operatorname{HCF}\left(F_{\text {film }}\right)$. Each of the random and systematic HCF components are described below and summarized in the tables of Appendix D.

Table 4 and Table 5 give the manufacturing tolerances and uncertainties considered in this analysis.

Table 4. Manufacturing tolerances considered by HCF.

\begin{tabular}{|c|c|}
\hline & Tolerance \\
\hline Water gap & $\pm 0.3 \mathrm{~mm}[12]$ \\
\hline${ }^{235} \mathrm{U}$ homogeneity on $1 \mathrm{~cm}^{2}$ & $\pm 20 \%[12]$ \\
\hline${ }^{235} \mathrm{U}$ plate loading & $-2.7 \%,+2 \%[13]$ \\
\hline
\end{tabular}

Table 5. Uncertainties in power and flow measurements.

\begin{tabular}{|c|c|}
\hline & Uncertainty \\
\hline Total core power & $\pm 3 \%[12]$ \\
\hline Total flow & $\pm 2 \%[12]$ \\
\hline
\end{tabular}

${ }^{235}$ U homogeneity (random)

The BR2 HEU and proposed LEU fuels are composed of fuel particles (UAI $\mathrm{I}_{\mathrm{x}}$ and uncoated U7Mo, respectively) dispersed in an aluminum matrix. The ${ }^{235} \mathrm{U}$ homogeneity reflects the fact that the fuel particles (corresponding to a given mass of ${ }^{235} \mathrm{U}$ ) are not perfectly mixed throughout the meat and therefore can produce a local increase in ${ }^{235} \mathrm{U}$ content. This local effect does not significantly increase 
the total energy in the hot channel (no impact on $F_{\text {bulk }}$ ) but does contribute to $F_{\text {film }}$ and $F_{\text {flux }}$. An uncertainty of $20 \%$ (over a $1 \mathrm{~cm}^{2}$ region) [13] is used in this analysis.

${ }^{235} \mathrm{U}$ plate loading (random)

The uncertainty in the ${ }^{235} \mathrm{U}$ loading of a fuel plate is typically in the range of a few percent. Ref. [13] states that, for a BR2 fuel assembly, the manufacturing tolerances on loading are $[-2.7 \%,+2 \%]$. Therefore, for this analysis, a conservative uncertainty of $\pm 2 \%$ is assumed. Note that only one of the two plates on each side of the hot channel (the limiting plate) is assumed to have a higher ${ }^{235} \mathrm{U}$ loading hence the factor of 0.5 is used when evaluating the contribution to $F_{\text {bulk }}$. The impact of this uncertainty on the evaluation of the $F_{\text {bulk }}$ HCF does not take credit for the fact that a larger fraction of the heat generated in plate 6 will flow into channel 7 (colder channel) instead of the hot channel (channel 6).

\section{Power density calculation (random)}

This component addresses the uncertainties of the reactor physics calculations of local power densities. It reflects the fact that more power could be generated at the hot spot than calculated. It combines uncertainties in the calculation of the power sharing between fuel assemblies as well as the uncertainties in power shape (axial, radial and azimuthal) within a fuel assembly. The uncertainties presented in the MCNP licensing file [14] are,

- Fuel assembly power: $5 \%$

- Axial power distribution: $10 \%$

- Radial power distribution: $5 \%$

- Azimuthal power distribution: $15 \%$

For this analysis, these uncertainties are statistically combined to yield a total uncertainty of $20 \%$.

\section{Channel spacing (random)}

This component reflects the impact of the manufacturing tolerances on the coolant channel gap and consequently, on the three HCFs. A tolerance fraction of 0.11 was obtained for the fresh fuel element (C-259 for HEU and C-319 for LEU) by dividing the coolant channel nominal thickness $\left(t_{\text {nom }}=3.0 \mathrm{~mm}\right.$ ) by the minimum thickness $\left(t_{\min }=t_{\text {nom }}-0.3 \mathrm{~mm}\right.$, see Table 4). Both $t_{\min }$ and $t_{\text {nom }}$ were reduced by the calculated oxide buildup and swelling (dimensions given in Table 1 and Table 2 ) to produce tolerance fraction values of 0.11 for the high heat flux element (A-30), 0.12 for the high power element $(\mathrm{H}-1)$ and 0.12 for the high burnup fuel element (F-346).

For turbulent flow in plate geometry (also applicable for a BR2 fuel assembly coolant channel) where the hydraulic diameter can be approximated as twice the channel thickness, the formulas [8] for obtaining $F_{\text {bulk }}$ and $F_{\text {film }}$ as a function of $t_{\text {nom }} / t_{\text {min }}$ are

$$
\begin{gathered}
F_{\text {bulk }}=\left(t_{\text {nom }} / t_{\text {min }}\right)^{3 /(2-\alpha)} \\
F_{\text {film }}=\left(t_{\text {nom }} / t_{\text {min }}\right)^{(0.4+\alpha) /(2-\alpha)}
\end{gathered}
$$


where $\alpha$ is the Reynolds number exponent in the friction factor relationship. The value of $\alpha$ is typically between 0.2 and 0.25 . For this analysis, an $\alpha$ of 0.25 was selected.

Flow distribution (random)

This uncertainty is the result of the hydraulic analysis that is used to determine the flow distribution among the coolant channels. This is a local effect that does not systematically affect all coolant channels. The determination of this uncertainty was based on the measurement of the flow speeds in the different coolant channels of a BR2 fuel assembly [15]. Appendix E shows that this uncertainty is on the order of $9 \%$. Moreover, Ref. [11] states that for a given pressure drop over the vessel, the mass flow rate in a given fuel assembly has a small dependency on the loading of the core. For an unfavorable but credible loading, the mass flow rate in a fuel assembly could be reduced by $4 \%$. For this analysis, these two uncertainties are statistically combined for a total uncertainty of $10 \%$ and applied to $F_{\text {bulk }}$ and $F_{\text {film. }}$.

\section{Single phase heat transfer correlation (systematic)}

Heat transfer correlations typically predict heat transfer coefficients that are accurate to within $10 \%$ to 15\%. A study [16] comparing the heat transfer coefficients predicted by various correlations and computational fluid dynamics (CFD) clearly showed that, for thermal-hydraulic conditions similar to a BR2 channel near ONB, the selected heat transfer correlation must take into account the variation in water viscosity between the bulk coolant and the coolant adjacent to the channel wall. The same study also shows that the correlations using variable properties (Seider-Tate [17], Dittus-Boelter-Modified (i.e., corrected for viscosity changes) [16] and Petukhov \& Popov [18]) and the CFD predict heat transfer coefficients within a range of $\pm 10 \%$. Since it is difficult to evaluate the true accuracy of any correlations for a configuration and regime (geometry, flow, power, pressure, etc.) representative of a BR2 channel near limiting $\mathrm{T}-\mathrm{H}$ conditions, a systematic error of $15 \%$ is applied to $\mathrm{F}_{\text {flux }}$.

\section{$\underline{\text { Hot stripe (systematic) }}$}

A hot stripe approach has been used to take into account the azimuthal power peak in PLTEMP since:

i. the azimuthal power peak for a sector can occur near the azimuthal center of a plate,

ii. the azimuthal heat conduction has a limited effect in reducing the heat flux at that location [16], and

iii. the coolant mixing effect is minimal in a BR2 channel at nominal operating conditions [16].

To model the hot stripe in PLTEMP, the azimuthal power peak-to-average ratio is used as a systematic

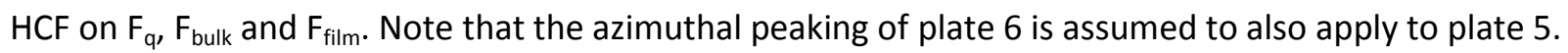

\section{Combination of random and systematic components}

The random combination of the components of each HCF reflects that it is unlikely that all local tolerances/uncertainties apply to the hot channel, at the most limiting axial location and at their worst possible values. Therefore, the components $\mathrm{F}^{\mathrm{i}}$ of each HCF are combined statistically using $F=1+$ 
$\sqrt{\sum_{i}\left(1-F^{i}\right)}$, i.e., assuming that they are independent and normally distributed. To obtain the final HCFs, the random HCFs are then multiplied by components reflecting systematic effects.

\subsection{Thermal hydraulic correlations}

The following are brief descriptions of the T-H models used in the PLTEMP code and described in the user manual [8].

\section{$\underline{\text { Heat Transfer Coefficient (HTC) }}$}

The single-phase HTC selected for this work was the modified Dittus-Boelter correlation [16]. It is the same well-known Dittus-Boelter correlation [19] except that it contains an additional term for the bulk and wall viscosity ratio $\left(\left[\mu / \mu_{w}\right]^{0.11}\right)$. It has been shown to better account for the temperature dependence of the coolant properties that are important at high heat flux and was the most conservative of the correlations evaluated in Ref. [16].

Onset of Nucleate Boiling Ratio (ONBR)

The Bergles-Rohsenow correlation [20] was used to determine the heat flux representing the onset of nucleate boiling.

\section{Fully developed Nucleate Boiling Ratio (FDNBR)}

The Forster and Greif correlation [21] was used to determine the heat flux at which fully developed nucleate boiling begins ${ }^{3}$.

Onset of Flow Instability Ratio (OFIR)

The correlation by Whittle and Forgan [22] was used in this work to determine the onset of flow instability ratio (OFIR). The PLTEMP user manual recommends an empirical value of 32.5 for the coefficient $\eta$ used in the Whittle and Forgan correlation. However, a statistical analysis described in the user manual determined that $\eta=24.93$ produces a best estimate of the heat flux at which OFI occurs and results in a fair comparison with the Groeneveld CHF lookup table. To be consistent with the work presented in Ref. [2], a value of $\eta=24.93$ was used in this work. However, it should be noted that increasing $\eta$ to 32.5 reduces the peak heat flux by less than $5.1 \%$ while increasing the confidence interval that the flow is stable from $50 \%$ to $95 \%$ [2].

\section{Critical Heat Flux Ratio (CHFR)}

The standard Groeneveld 2006 CHF lookup table [23] is valid for mass velocities up to $8000 \mathrm{~kg} / \mathrm{m}^{2}-\mathrm{s}$; however, the values for the BR2 analyses range from $1040-16744 \mathrm{~kg} / \mathrm{m}^{2}-\mathrm{s}$. An extended version of this

\footnotetext{
${ }^{3}$ The PLTEMP user guide describes both the Bergles-Rohsenow and Forster and Greif correlations as being applicable for determining the onset of nucleate boiling. However, the Bergles-Rohsenow correlation was developed to determine the heat flux at which nucleate boiling just starts to occur (onset of). The Forster and Grief correlation was developed to determine the lowest heat flux at which nucleate boiling has been fully established (i.e. at a slightly higher heat flux than that predicted by the Bergles-Rohsenow correlation).
} 
lookup table described in Ref. [24] is stated to be valid up to $30,000 \mathrm{~kg} / \mathrm{m}^{2}$-s by including a mass flux correction term applied to cases exceeding $8000 \mathrm{~kg} / \mathrm{m}^{2}$-s. Additionally, an adjustment to the exponent of the diameter factor was included in the CHF calculation and is applicable to all mass velocities. The extended Groeneveld 2006 CHF lookup table was available in PLTEMP version 4.2.bta of July 5, 2012 (SVN version 61).

\section{Computational Results and Discussion}

The $\mathrm{T}-\mathrm{H}$ criteria and fuel temperature results for the high heat flux fuel assembly ${ }^{4}$, have been updated for the current representative core (numerical results are given in Appendix F). Similar to previous work, a search was performed to determine the heat flux, sector power, peak cladding temperature and peak fuel temperature for each of the limiting $\mathrm{T}-\mathrm{H}$ criteria at four percentages of the nominal flow rate: $1 \%$, $20 \%, 100 \%$ and $161 \%$ (maximum flow based on allowed pressure drop).

Figure 4 and Figure 5 show the calculated heat flux as a function of the percentage of nominal flow $(10.4 \mathrm{~m} / \mathrm{s}$ at $100 \%$ flow), for both HEU and LEU cores. The allowed operating regions are also illustrated for both thermal limits: $470 \mathrm{~W} / \mathrm{cm}^{2}$ (short dashes) and $600 \mathrm{~W} / \mathrm{cm}^{2}$ (long dashes). It can be seen that the margins to OFI or CHF are greater than 1.5 for either maximum heat flux $\left(470 \mathrm{~W} / \mathrm{cm}^{2}\right.$ and $\left.600 \mathrm{~W} / \mathrm{cm}^{2}\right)$ for mass flow rates above $\sim 70 \%$ nominal. For nominal operating conditions the margins are greater than 2. It can also be seen that the most conservative criterion (ONBR) is met for both heat flux limits when the mass flow rate is above the minimum flow lines.

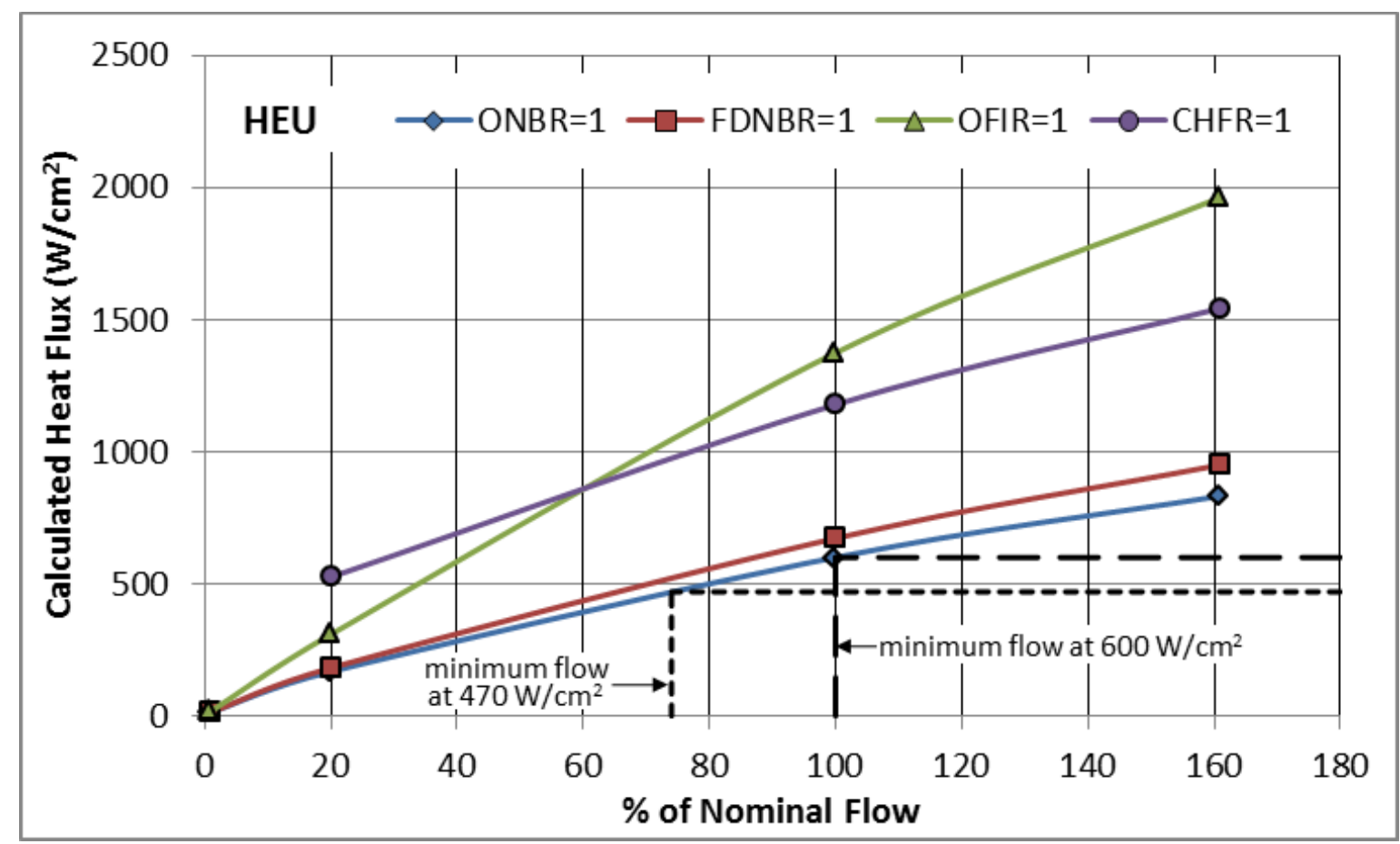

Figure 4 HEU core limiting conditions as a function of average coolant flow.

\footnotetext{
${ }^{4}$ For the representative core analyzed in Ref. [2] and [3], the high heat flux assembly was located at C-259. For the current representative core, the highest heat flux fuel assembly is located at A-30.
} 


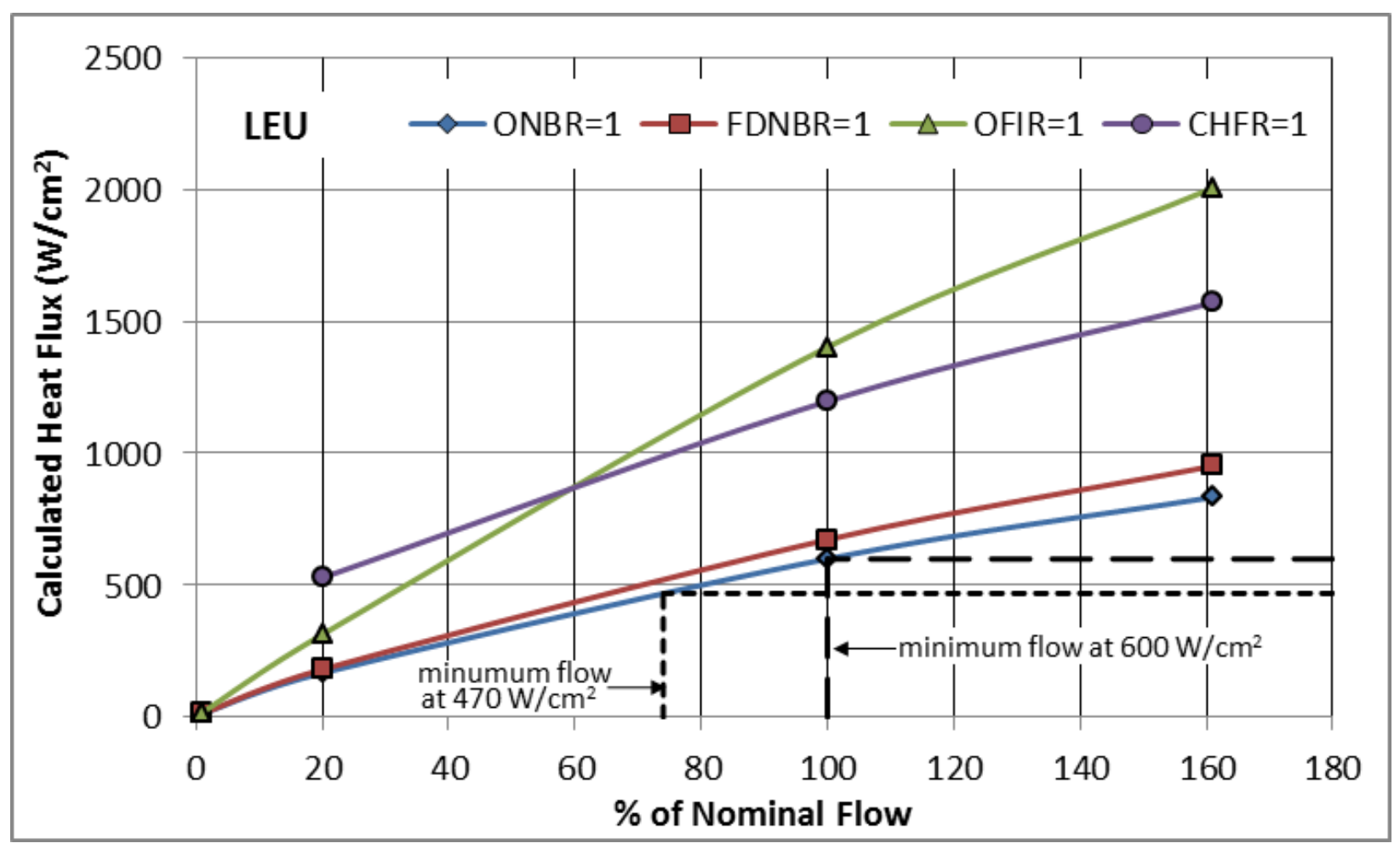

Figure 5 LEU core limiting conditions as a function of average coolant flow.

\section{$\underline{\text { ONBR Margin }}$}

Figure 6 shows a comparison of the HEU and LEU cores with respect to ONB. It can be seen that:

1. ONB occurs at nearly the same heat flux for both cores;

2. The allowed operational regimes are almost identical for both cores;

3. The margin from nominal to minimum flow (about $26 \%$ at $470 \mathrm{~W} / \mathrm{cm}^{2}$ ) is larger than the uncertainty of the flow measurements ( $2 \%$, see Table 5$)$. A similar margin would be obtained for $600 \mathrm{~W} / \mathrm{cm}^{2}$ at a flow of $\sim 125 \%$. There is no margin at $600 \mathrm{~W} / \mathrm{cm}^{2}$ at nominal flow (100\%);

4. The margin from ONBR $=1$ at nominal flow (about $28 \%$ at $470 \mathrm{~W} / \mathrm{cm}^{2}$ ) is larger than the uncertainty in power measurement (3\%, see Table 5). Again, a similar margin would be obtained for $600 \mathrm{~W} / \mathrm{cm}^{2}$ at a flow of $\sim 125 \%$. There is no margin at $600 \mathrm{~W} / \mathrm{cm}^{2}$ at nominal flow (100\%). 


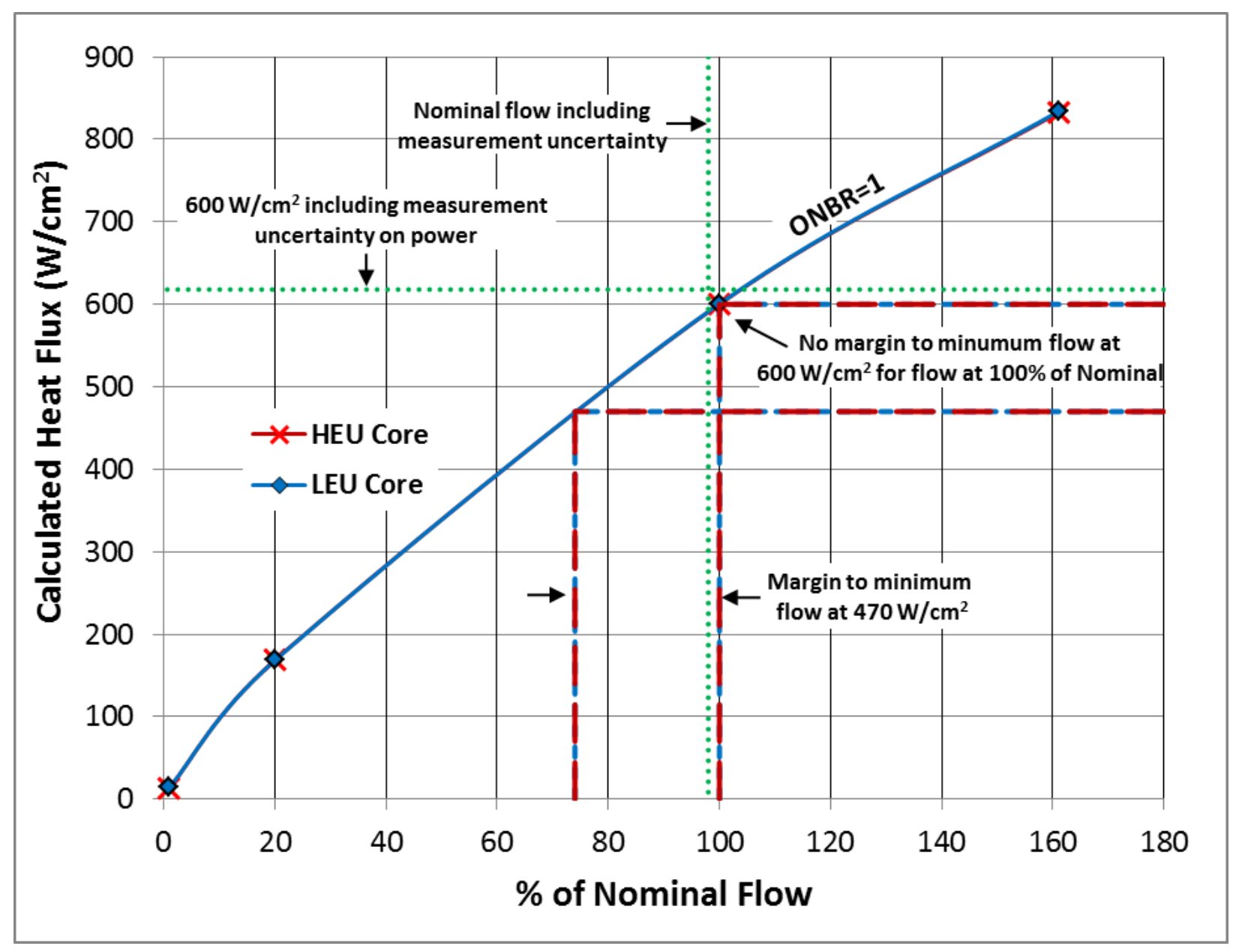

Figure 6 Thermal performance comparison for the HEU and LEU cores $(O N B R=1.0)$

A difference between this and the previous analysis of Ref. [1] is that the margins for a heat flux of 600 $\mathrm{W} / \mathrm{cm}^{2}$ have been eliminated. Previously, the margin from nominal to minimum flow was $5 \%$ (greater than the $2 \%$ flow uncertainty) and the margin from ONBR = 1 was on the order of the $3 \%$ power uncertainty.

To investigate the reason for these differences, a series of analyses were performed for the high heat flux element (A-30) in the HEU core (see Appendix G). Beginning with a PLTEMP input file from the previous work, the model was updated (e.g. HCFs, power distribution, modeling method, etc.) in a stepby-step method to determine the impact each change in the model had on the limiting heat flux for ONB. It was determined that the change in axial power distribution and thermal resistance of the fuel plate contributed a $\sim 1 \%$ and $\sim 1.5 \%$ change in heat flux, respectively, relative to previous work (i.e. previously defined representative core). There was no significant effect on the ONB heat flux due to switching from the 3-layer to 5-layer plate model (about -0.3\% change). 


\section{$\underline{\text { CHF/OFI crossover point }}$}

Figure 4 and Figure 5 also show the $\mathrm{CHF}$ and OFI limit for a range of flow rates. There is a crossover of the OFI and CHF curves at about $60 \%$ of nominal flow for both the HEU and LEU cores. This has changed relative to previous work [2] where the crossover was about $105 \%$ of nominal flow. In addition to the updated representative core configuration, there were two reasons for this change. First, the modeling approach has been changed by switching from the 3-layer to 5-layer plate model. As shown in the sensitivity study described in Appendix G, this change resulted in a decrease of the CHF by $1.7 \%$ $\left(1437 \mathrm{~W} / \mathrm{cm}^{2}\right.$ to $\left.1413 \mathrm{~W} / \mathrm{cm}^{2}\right)$. The second and more significant reason for the change is that the previous analysis used what is known as the direct substitution method (DSM) [23] (i.e. option 14 set to 0 on card 200 of PLTEMP input file), where the CHF margin is predicted from the constant local conditions. However, as described in Ref. [23] and [25], the accuracy of CHF margin using the CHF lookup table is improved by using the heat balance method (HBM) (option 14 set to 1 on card 200 of PLTEMP input file), where the power is iteratively increased until the CHF is met. For HEU fuel at $100 \%$ flow, switching to the more accurate HBM results in a decrease by $17 \%$ in predicted $\mathrm{CHF}$ from $1413 \mathrm{~W} / \mathrm{cm}^{2}$ (Appendix G) to $1178 \mathrm{~W} / \mathrm{cm}^{2}$ (Appendix F). This updated analysis approach shows that $\mathrm{CHF}$ is the limiting safety criterion, with respect to OFI, for flow rates greater than $60 \%$ of nominal.

\section{Additional analyses to determine the limiting fuel assembly}

Analyses were also performed to verify that the high heat flux fuel assembly (A-30) is the limiting assembly for both the HEU and LEU cores with respect to the T-H criteria (ONBR, FDNBR, OFIR and CHFR) and fuel temperature. The limiting heat flux, and hence power, for each T-H criteria has been determined for the high heat flux assembly (A-30) and is given in Tables F-1 and F-2. Utilizing these power values, the power in the fresh fuel (C-259 for HEU and C-319 for LEU), high power ( $\mathrm{H}-1$ ) and high burnup (F-346) assemblies was calculated using the known power ratio between these assemblies and the high heat flux assembly (given in Tables C-1 to C-4). PLTEMP simulations were run with these calculated powers (no search was performed) to obtain the T-H margin and fuel temperature ${ }^{5}$.

Figure 7 shows the ONBR, FDNBR, OFIR and CHFR values for the fresh fuel (C-259 for HEU and C-319 for LEU), high heat flux (A-30), high power ( $\mathrm{H}-1$ ) and high burnup (F-346) assemblies for both the HEU and LEU cores at $100 \%$ flow. Both cores show similar trends. The high heat flux assembly (A-30) is shown to be limiting for all T-H margins with respect to the fresh fuel and high burnup fuel assemblies. Similar T-H values were obtained for the high heat flux $(\mathrm{A}-30)$ and high power $(\mathrm{H}-1)$ fuel assemblies. Thus, the high heat flux fuel assembly (A-30) can be considered the limiting assembly with respect to ONBR, FDNBR, FIR and CHFR for both the HEU and LEU cores at $100 \%$ flow. However, T-H margin calculations should be performed and re-evaluated for the high power fuel assembly $(\mathrm{H}-1)$ if there are any changes in the representative core or material properties.

\footnotetext{
${ }^{5}$ For example: the sector power in the high heat flux assembly (A-30) with HEU was determined to be $1.24 \mathrm{MW}$ for $O N B R=1$ and the ratio of power between the sector of the high heat flux assembly and the sector of the fresh fuel assembly ( $\mathrm{C}-259)$ is 0.678 . The power specified for the fresh fuel assembly (C-259) is then given by $1.24 \mathrm{MW}$ times 0.678 , or $0.84 \mathrm{MW}$. A PLTEMP calculation for the fresh fuel assembly (C-259) at this power (0.84 MW) gives an ONBR of 1.14, indicating that the high heat flux assembly (A-30) is the limiting fuel assembly for ONB.
} 


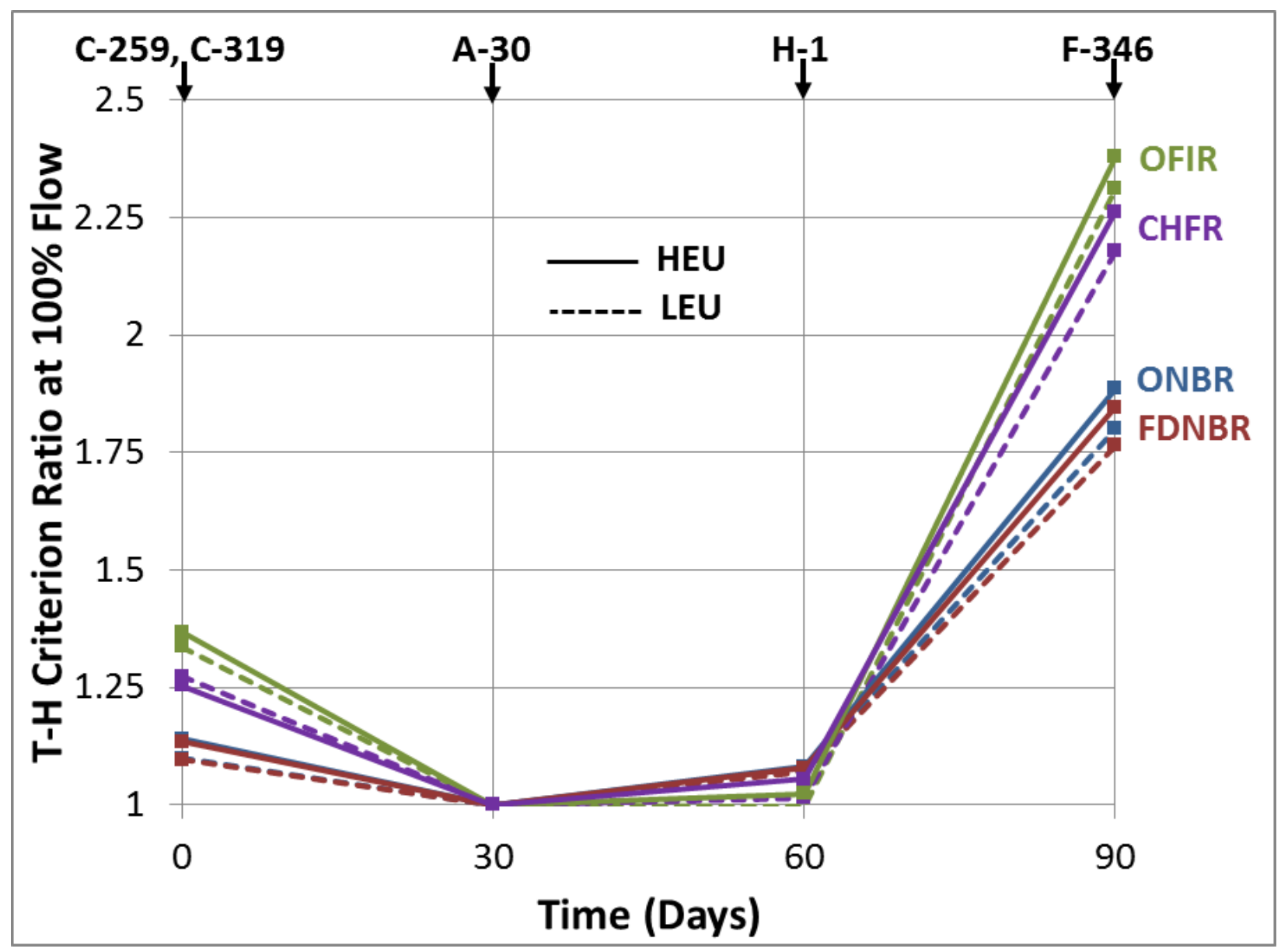

Figure $7 \mathrm{~T}-\mathrm{H}$ margins of the fresh fuel, high power and high burnup assemblies relative to the high heat flux assembly at $100 \%$ flow.

Figure 8 shows the maximum fuel temperature in plate 6 for each of the fuel assemblies at the maximum heat flux limits $\left(470 \mathrm{~W} / \mathrm{cm}^{2}\right.$ and $\left.600 \mathrm{~W} / \mathrm{cm}^{2}\right)$ for nominal flow. For HEU fuel, it can be seen that the highest fuel temperature occurs in the high heat flux fuel assembly (A-30). For LEU fuel, the fuel temperatures are nearly identical for the high heat flux (A-30) and high power (H-1) assemblies. Despite the degradation in meat conductivity and increased thermal resistance due to oxide growth at the cladding surface, the high burnup fuel assembly (F-346) has the lowest fuel temperature for both cores. Thus, the high heat flux (A-30) or high power ( $\mathrm{H}-1)$ fuel assembly can be considered the limiting assembly with respect to fuel temperature for the maximum nominal and temporary heat flux limit at $100 \%$ flow. However, fuel temperature calculations should be performed and re-evaluated for the high power assembly $(\mathrm{H}-1)$ if there are any changes in the representative core or material properties. The fuel temperature at $100 \%$ flow for the LEU core is $4.2 \%$ and $4.4 \%$ greater than the HEU core for a heat flux of $470 \mathrm{~W} / \mathrm{cm}^{2}$ and $600 \mathrm{~W} / \mathrm{cm}^{2}$, respectively. The results also show that the LEU fuel temperature remains below the recommended [26] blister threshold temperature of $450^{\circ} \mathrm{C}$ by $235^{\circ} \mathrm{C}$ for $470 \mathrm{~W} / \mathrm{cm}^{2}$ and $192^{\circ} \mathrm{C}$ for $600 \mathrm{~W} / \mathrm{cm}^{2}$.

\footnotetext{
${ }^{6}$ The actual blister threshold temperature for the proposed LEU fuel has not yet been measured.
} 


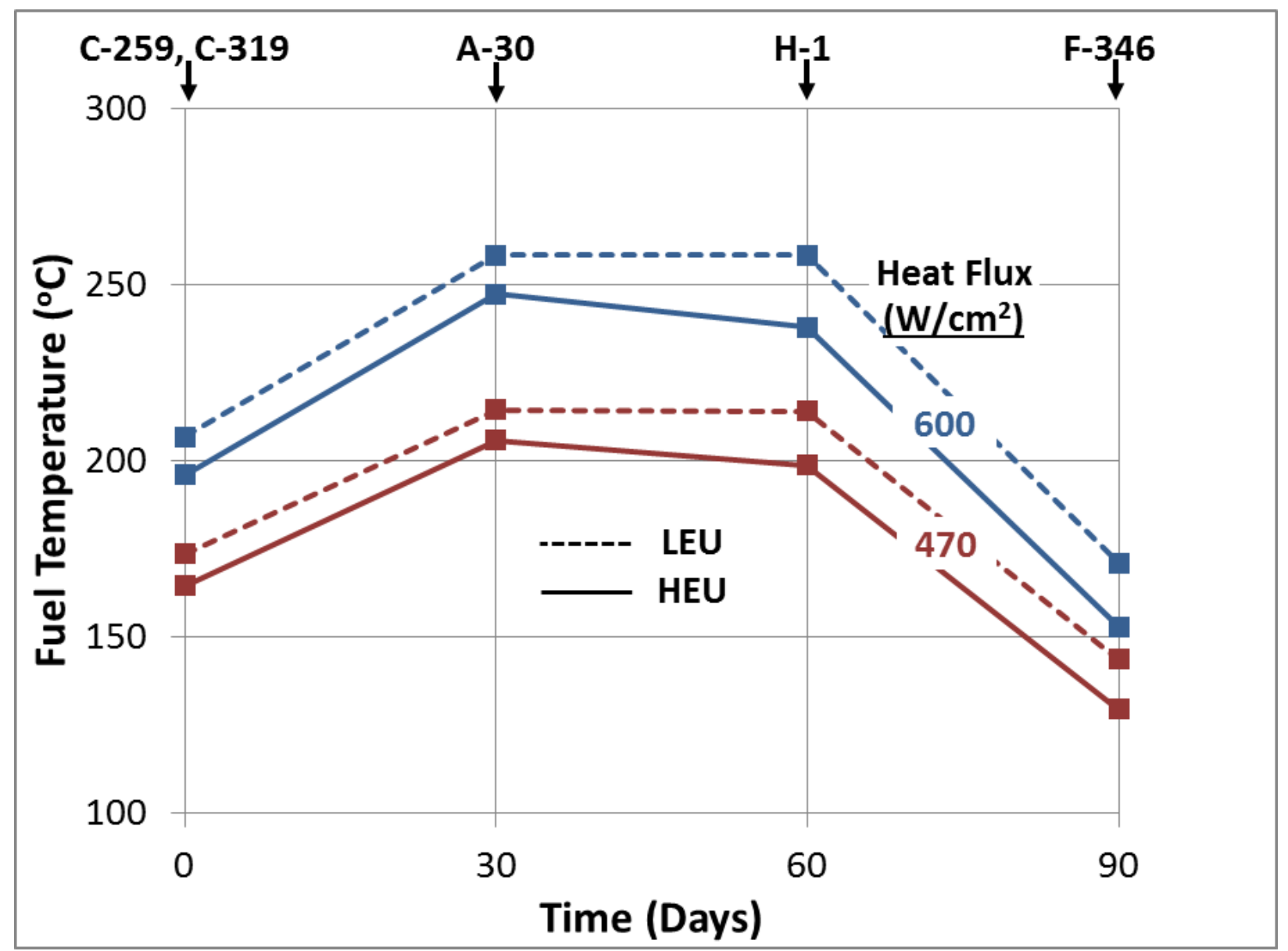

Figure 8. Maximum fuel temperature in limiting fuel element of each cycle group for HEU and LEU.

Due to the significant uncertainty in predicting the thermal resistance of the fuel plate, a propagation of uncertainties was performed for the $470 \mathrm{~W} / \mathrm{cm}^{2}$ case to further investigate the peak fuel temperature, its uncertainty and the dominate contributing factors. Figure 9 and Figure 10 show the results for the HEU and LEU core using, where applicable, the following values [10] and estimated uncertainties:

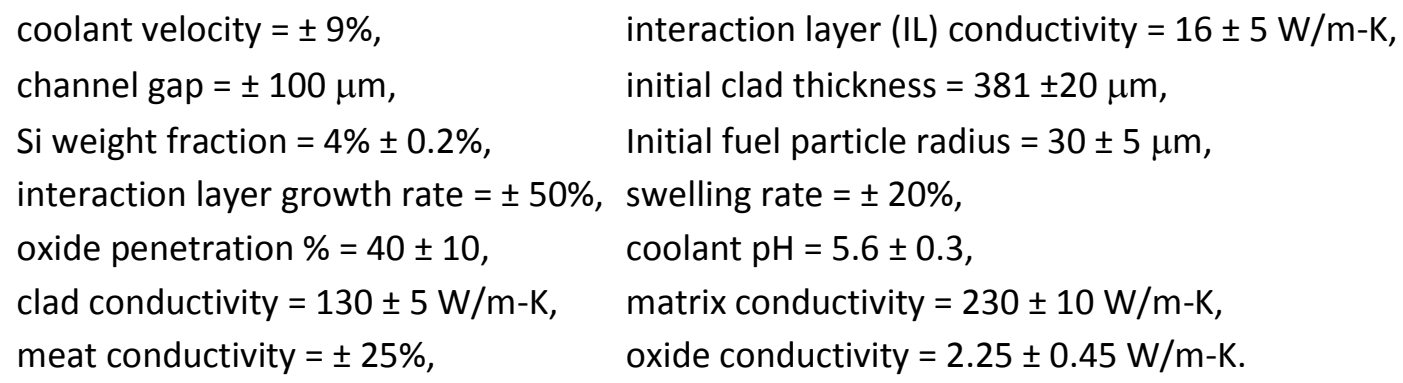

The magnitude and evolution of the fuel temperatures and uncertainties are similar for the HEU and LEU cores. However, the LEU fuel temperature uncertainty appears larger than the HEU core since it was calculated with a more detailed model containing additional uncertainty factors [10]. The coolant velocity was found to be the largest contributor for fresh fuel at beginning of cycle, although the 
magnitude of the fuel temperature uncertainty is relatively small at this time. The relevance of the coolant velocity uncertainty decreases continuously for fresh fuel as the uncertainty contribution of the $\mathrm{pH}$ steadily increases. For the remaining fuel assemblies, the $\mathrm{pH}$ is the dominate uncertainty contributor. The $\mathrm{pH}$ not only impacts the thermal resistance of the cladding oxide, but also other parameters that are dependent on the fuel temperature; such as the interaction layer growth rate and conductivity. Ultimately, the uncertainty in fuel temperature shows that despite the limited knowledge on parameters impacting the heat transfer from the fuel, the high heat flux $(A-30)$ or high power $(H-1)$ fuel assembly can be considered the limiting assembly with respect to fuel temperature. Further, taking into consideration the uncertainties in the fuel temperature there is still significant margin from the recommended blister threshold temperature for LEU fuel.

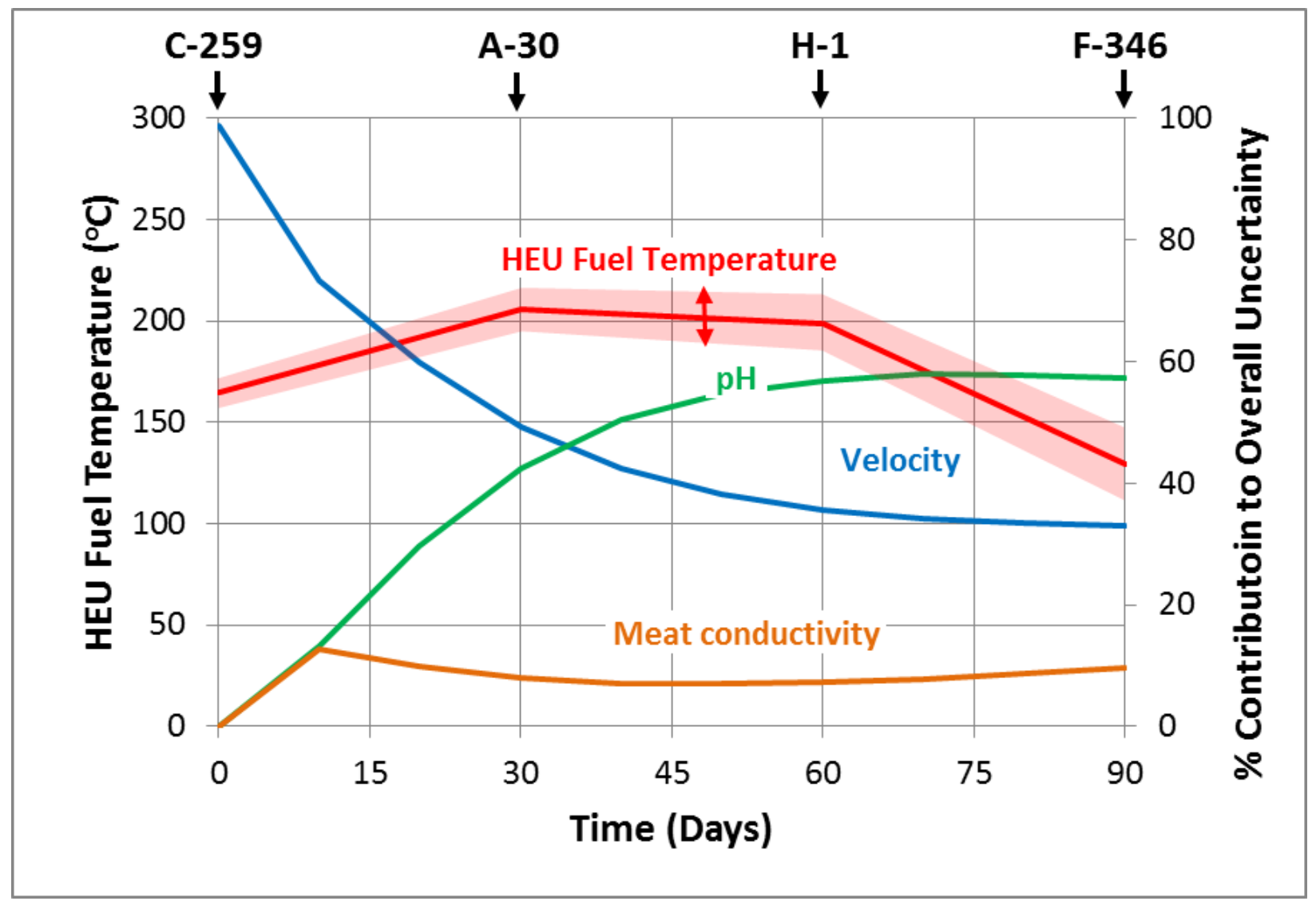

Figure 9 HEU fuel temperature with uncertainty and contributing factors for $470 \mathrm{~W} / \mathrm{cm}^{2}$. 


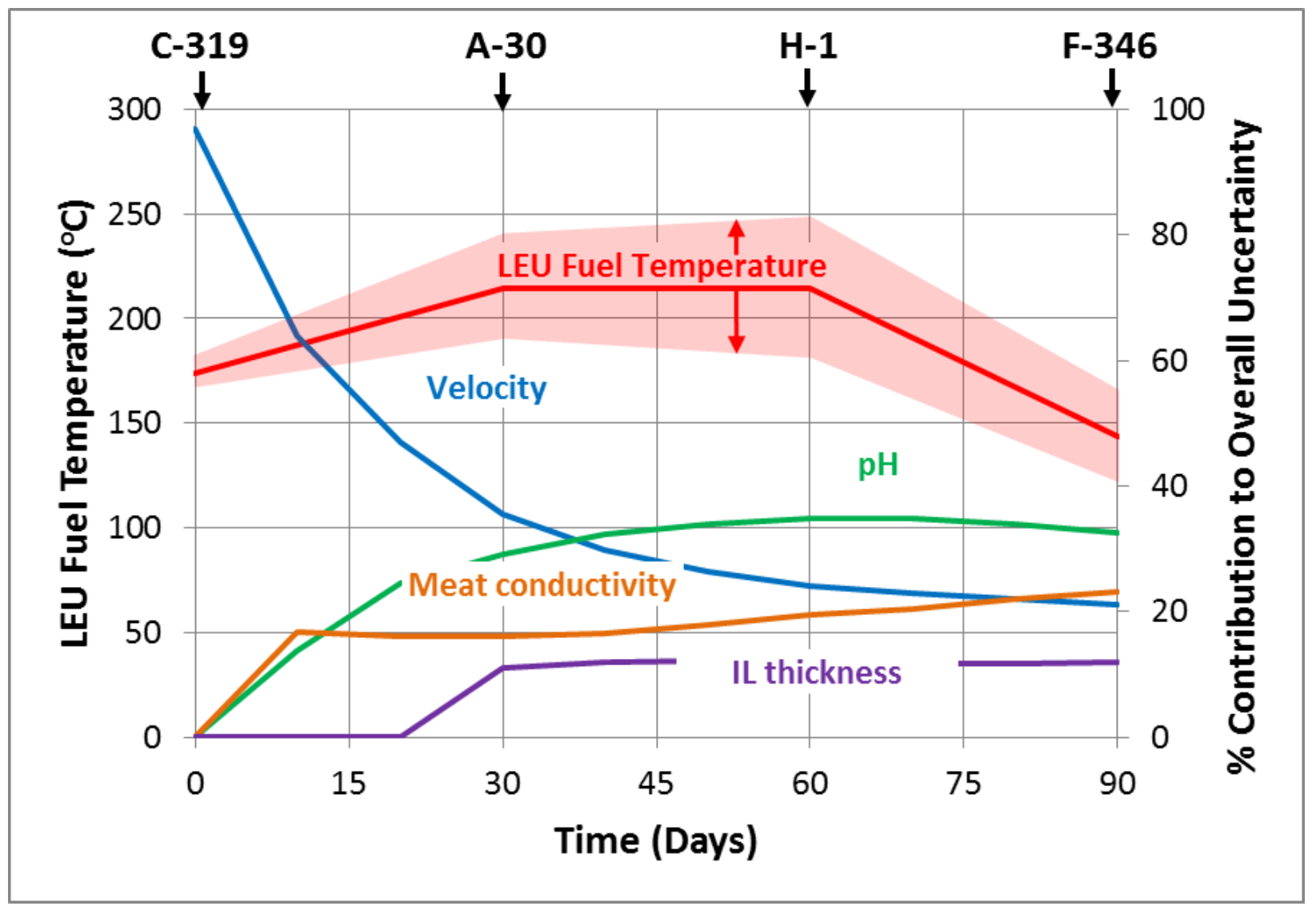

Figure 10 LEU fuel temperature with uncertainty and contributing factors for $470 \mathrm{~W} / \mathrm{cm}^{2}$.

\section{Summary and Conclusions}

The objective of this work was to update the thermal hydraulic safety margin and fuel temperature analyses associated with converting the BR2 reactor core with the proposed LEU fuel assembly. This update was required due to changes in the representative core configuration used for core conversion analyses. The analyses were also extended to the fresh fuel (C-259 for HEU and C-319 for LEU), high power ( $\mathrm{H}-1)$ and high burnup ( $\mathrm{F}-346)$ fuel assemblies to verify that the high heat flux fuel assembly (A-30) is the limiting assembly for all T-H criteria.

Relative to previous work, the analysis showed that the thermal hydraulic limits for the high heat flux assembly (A-30) were again very similar for both the HEU and LEU cores. However, the change in core configuration and the incorporation of a more accurate material properties model has shown that there is no margin to ONBR $=1$ for the temporary heat flux limit of $600 \mathrm{~W} / \mathrm{cm}^{2}$ at nominal flow (100\%). Significant margin to minimum flow (26\%) and for power (28\%) still exists for the maximum nominal heat flux of $470 \mathrm{~W} / \mathrm{cm}^{2}$.

Results show that the crossover for $\mathrm{CHF}$ and $\mathrm{Fl}$ occurs at $60 \%$ of nominal flow as compared to $105 \%$ seen in the previous analysis [1]. The primary difference was shown to be due to switching from the DSM to the more accurate HBM for determining CHF margin. For HEU fuel at $100 \%$ flow, the HBM resulted in a 
decrease in predicted $\mathrm{CHF}$ from $1413 \mathrm{~W} / \mathrm{cm}^{2}$ to $1178 \mathrm{~W} / \mathrm{cm}^{2}$. The updated analysis approach shows that CHF is the limiting safety criterion, with respect to OFI, for flow rates greater than $60 \%$ of nominal.

Further analyses of the fresh fuel (C-259 for HEU and C-319 for LEU), high power ( $\mathrm{H}-1)$ and high burnup (F-346) assemblies verified that the high heat flux fuel assembly (A-30) was the limiting assembly with respect to ONB, FDNB, OFI and CHF. However, in some instances the T-H margins of the high power assembly ( $\mathrm{H}-1)$ was similar to the high heat flux assembly ( $\mathrm{A}-30)$ at nominal flow. Thus, the $\mathrm{T}-\mathrm{H}$ margins for the high power assembly $(\mathrm{H}-1)$ should be re-evaluated if there are any changes in the representative core configuration or the material properties of the fuel assemblies.

The fuel temperatures for the four assembly types in the LEU core are relatively higher than the HEU core (by about $4 \%$ to $11 \%$ ) due to the degradation in thermal conductivity associated with burnup. For both cores, it was found that the highest temperature occurs in both the high heat flux $(A-30)$ and high power $(\mathrm{H}-1)$ assemblies, as both produced similar values. A propagation of uncertainties was performed to better characterize the uncertainty in parameters impacting the fuel temperature. From this it was determined that, despite limited knowledge of thermal conductivities and surface oxide thickness, both the high heat flux (A-30) and high power (F-346) assembly can obtain similar temperatures and that they are significantly greater than the fresh fuel and high burnup fuel assemblies. Thus, the high heat flux (A-30) or high power ( $\mathrm{H}-1)$ fuel assembly can be considered the limiting assembly with respect to fuel temperature. It was also shown that the LEU fuel temperature, including uncertainties, was below the recommended blister threshold temperature of $450^{\circ} \mathrm{C}$ by $235^{\circ} \mathrm{C}$ for $470 \mathrm{~W} / \mathrm{cm}^{2}$ and $192^{\circ} \mathrm{C}$ for $600 \mathrm{~W} / \mathrm{cm}^{2}$.

Finally, it should be stated that this work provides preliminary conclusions that will need to be updated once the LEU fuel assembly has been finalized and measurements of the blister threshold temperature, fuel thermal conductivity, etc. have been made available.

\section{References}

[1] S. Kalcheva, E. Koonen, V. Kuzminov, G. Van den Brandon, A.P. Olson, B. Dionne, J. Stevens, "Feasibility Report: Conversion HEU to LEU BR2 Reactor," SCK-CEN-R-5439, August, 2012.

[2] M. Kalimullah, A.P. Olson, E. E. Feldman, B. Dionne, S. Kalcheva, G. Van den Branden and E. Koonen, "Reversal of OFI and CHF in Research Reactors: Application to the BR2 HEU and LEU Cores", European Research Reactor Conference, Slovenia, March 30 ${ }^{\text {th }}-$ April $3^{\text {rd }}, 2014$.

[3] "Volume 2: BR2 operation and operational safety," SCK・CEN dossier Vol VI; 72S7680 : Reactor BR2, vol 2-4-2, SCK•CEN 2007-10-11 SAR001-3.1-ed 3.

[4] S. Fabrega, "Le calcule thermique des réacteurs de recherché refroidis a l'eau," -CEA-R-4114, 1971.

[5] Andre Beeckmans, "Summary of studies carried out for the definition of the maximum allowed heat flux in the BR2 reactor," GEX-R-159, 1987-Jan-19. 
[6] "Volume 3: Technische specificities," SCK•CEN dossier Vol VI; 72S7680: Reactor BR2, vol 3-1-2, SCK•CEN 2007-10-11 SAR001-3.1-ed 3.

[7] S. Kalcheva, E. Koonen, B. Dionne, C. Tzanos, A. Olson, M. Kalimullah, E. Feldman, "Preliminary Evaluation of Safety Margins of HEU and LEU BR2 cores", SCK•CEN Report, BLG-1079, 12 December, 2010.

[8] A.P. Olson and M. Kalimullah, "A User's Guide to PLTEMP/ANL Code," ANL/RERTR/TM-11/22 Rev.1 Version 4.2, Argonne National Laboratory, Argonne, IL, USA (July 7 2015).

[9] G. Van den Branden, "Conversion Study; Design Basis Document Reference Cores," SCK•CEN, BR2/RCE/GVdB/2010/conversion_DBD_reference_cores-ed3, August 2010.

[10] B. Dionne, A. Bergeron, J.R. Licht, Y.S. Kim and G.L. Hofman, "Thermal Properties for the Thermal-hydraulics Analyses of the BR2 Maximum Nominal Heat Flux," ANL/RERTR/TM-11-20, Rev. 1, Jan 2015.

[11] "Refroidissement du BR-2 en fonctionnement nominal," Technical note 71/2435/07/Fsm, Grouped d'exploitation du BR2 et de ses installations connexes, October 1962.

[12] A. Beeckmans, H. Lenders, F. Leonard, "Definition du flux de chaleur maximum admissible dans les conditionnes normales de refroidissement d'une charge du réacteur BR2", CEN-Euroatom, Dept. BR2, 72.0616, 1977.

[13] CERCA Spécification Technique des éléments combustibles du réacteur BR2 J-45-A-1081 Rev.2.

[14] S. Kalcheva, E. Koonen, V. Kuzminov, G. Van den Branden, "MCNPX 2.7 Licensing Package BR2; Licensing File for MCNPX 2.7 Methodologies Applied for Reactor Core Management at BR2", SCK•CEN-R-5188 (Rev. 1), June 07, 2011.

[15] Planquart, J., Huberlant, M., Mathieu, F., Tytgat, D., De Meester, P., "Fuel Elements in the Form of Concentric Cylindrical Plates," Geneva Conference on Peaceful Uses of Atomic Energy, 1964.

[16] C.P. Tzanos and B. Dionne, "Computational Fluid Dynamics Analyses of Lateral Heat Conduction, Coolant Azimuthal Mixing and Heat Transfer Predictions in a BR2 Fuel Assembly Geometry," ANL/RERTR/TM-11-21, Argonne National Laboratory, 2011.

[17] E. N. Sieder and G. E. Tate, "Heat Transfer and Pressure Drop of Liquids in Tubes," Ind. Eng. Chem., 28, 1429 (1936). See also M. M. El-Wakil, "Nuclear Power Engineering," McGraw-Hill Book. Company, New York, Eq. (10-25), 1962.

[18] B. S. Petukhov and V. N. Popov, "Theoretical Calculation of Heat Exchange in Turbulent Flow in Tubes of an Incompressible Fluid with Variable Physical Properties," High Temp., 1, No. 1, pp 69-83, 1963. 
[19] F.W. Dittus and L.M.K Boelter, "Heat Transfer in Automobile radiators of the tubular type," University of California Publications in Engineering, 1930, 2, 443-461.

[20] A.E. Bergles and W.M. Rohsenow, "The Determination of Forced-Convection Surface-Boiling Heat Transfers," Trans. ASME, J. Heat Transfer 86, 365 (1964).

[21] Roger Ricque and Roger Siboul, "Ebullition Locale De L'eau En Convection Forcee," Report CEAR-3894, CEA Grenoble, May 1970.

[22] R.H. Whittle and R. Forgan, "A Correlation for the Minima in the Pressure Drop Versus Flow-Rate Curves for Subcooled Water Flowing in Narrow Heated Channels," Nucl. Eng. Design 6,89, 1967.

[23] D.C. Groeneveld, J.Q. Shan, A.Z. Vasic, L.K.H. Leung, A. Durmayaz, J. Yang, S.C. Cheng, and A. Tanase, "The 2006 CHF Look-up Table," Nucl. Eng. and Design, Vol. 237, pp. 1909-1922 (2007).

[24] M. Kalimullah, E.E. Feldman, A.P. Olson, B. Dionne, J.G. Stevens, and J.E. Matos, "An Evaluation of Subcooled CHF Correlations and Databases For Research Reactors Operating at 1 to 50 bar Pressure," $34^{\text {th }}$ International meeting on reduced enrichment for research and test reactors, October 14-17, Warsaw, Poland (2012).

[25] G.P. Celata, "On the Application Method of Critical Heat Flux Correlations," Nuclear Engineering and Design, Vol. 163, pp. 241-242, 1996.

[26] Good Practices for Qualification of High Density Low Enriched Uranium Research Reactor Fuels. IAEA Nuclear Energy Series No. NF-T-5.2, 2009. 


\section{APPENDICES}

\section{A. Fuel Assembly Map}

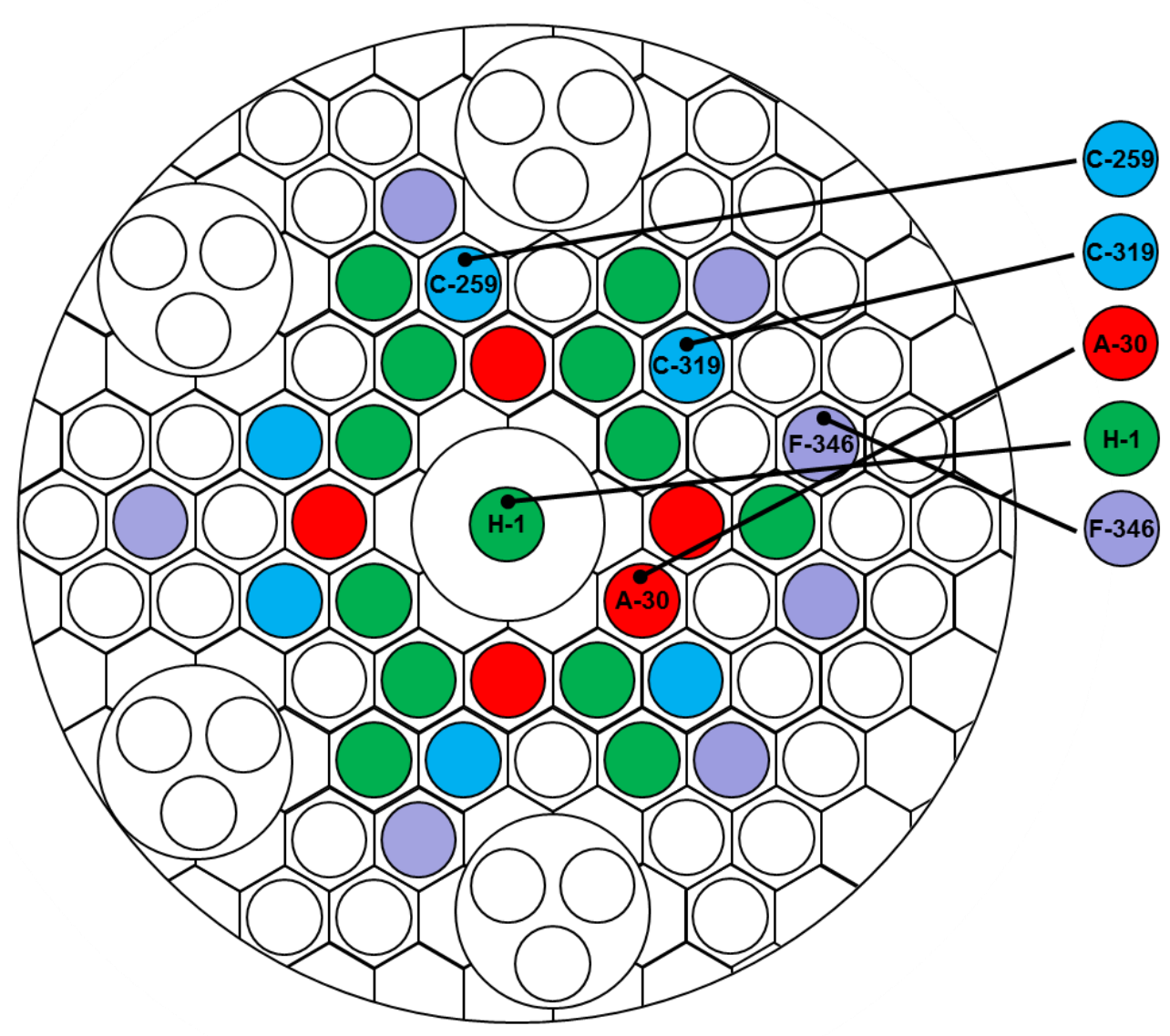

Location of Highest Heat Flux Fuel Assembly For Each Cycle Group

$1^{\text {st }}$ cycle, 0\% Burnup, Fresh Fuel (HEU)

$1^{\text {st }}$ cycle, 0\% Burnup, Fresh Fuel (LEU)

$2^{\text {nd }}$ cycle, $16 \%$ Burnup, High Heat Flux (HEU/LEU)

$3^{\text {rd }}$ cycle, 32\% Burnup, High Power (HEU/LEU)

$4^{\text {th }}$ cycle, $46 \%$ Burnup, High Burnup (HEU/LEU)

Figure A-1 Location of the highest heat flux fuel assembly for each cycle group shown in the representative core configuration (cross sectional view). 


\section{B. Fuel Assembly Geometry}

Table B-1. Power distribution for the channel C-259 (HEU) and C-319 (LEU) fuel assemblies (fresh fuel).

\begin{tabular}{|c|c|c|c|c|}
\hline Component & $\begin{array}{c}\text { Inner radius } \\
(\mathrm{m})\end{array}$ & $\begin{array}{c}\text { Outer radius } \\
(\mathrm{m})\end{array}$ & $\begin{array}{c}\text { Plate arc length } \\
(\mathrm{m})\end{array}$ & $\begin{array}{c}\text { Fuel meat arc length } \\
(\mathrm{m})\end{array}$ \\
\hline Central aluminum plug & & 0.12500 & & \\
\hline Plate 1 & 0.01598 & 0.01725 & 0.02922 & 0.02645 \\
\hline Plate 2 & 0.02024 & 0.02151 & 0.03814 & 0.03520 \\
\hline Plate 3 & 0.02451 & 0.02578 & 0.04708 & 0.04438 \\
\hline Plate 4 & 0.02878 & 0.03005 & 0.05603 & 0.05290 \\
\hline Plate 5 & 0.03305 & 0.03432 & 0.06497 & 0.06231 \\
\hline Plate 6 & 0.03731 & 0.03858 & 0.07389 & 0.07039 \\
\hline Beryllium channel & 0.42100 & & & \\
\hline
\end{tabular}

Meat thickness is $5.1 \mathrm{e}-4 \mathrm{~m}$.

Clad thickness is $3.8 \mathrm{e}-4 \mathrm{~m}$. 


\section{Power Distribution Tables}

This appendix presents the power distributions calculated from MCNP5. As described in Section 3.5, $\mathrm{FACTF}_{\mathrm{k}}$ was defined as the average power density in a given plate $(\mathrm{k})$ relative to the average power density of the sector.

Table C-1. Power distribution for the channel C-259 (HEU) and C-319 (LEU) fuel assemblies (fresh fuel).

\begin{tabular}{|c|c|c|c|c|c|c|c|c|c|c|c|c|}
\hline \multirow[b]{3}{*}{$\begin{array}{l}\text { Axial Position } \\
\text { of cell center } \\
(\mathrm{cm})\end{array}$} & \multicolumn{6}{|c|}{ HEU, Channel C-259 (Fresh fuel) } & \multicolumn{6}{|c|}{ LEU, Channel C-319 (Fresh fuel) } \\
\hline & \multicolumn{12}{|c|}{ QAVG $_{k, n}$, Relative Power Density Distribution in Plate (Plate Average $=1$ ) } \\
\hline & $\begin{array}{c}\text { 1st } \\
\text { plate } \\
\text { (inner) }\end{array}$ & $\begin{array}{l}\text { 2nd } \\
\text { plate }\end{array}$ & $\begin{array}{l}\text { 3rd } \\
\text { plate }\end{array}$ & $\begin{array}{l}\text { 4th } \\
\text { plate }\end{array}$ & $\begin{array}{l}\text { 5th } \\
\text { plate }\end{array}$ & $\begin{array}{c}\begin{array}{c}\text { 6th } \\
\text { plate } \\
\text { (outer) }\end{array} \\
\end{array}$ & $\begin{array}{c}\begin{array}{c}\text { 1st } \\
\text { plate } \\
\text { (inner) }\end{array} \\
\end{array}$ & $\begin{array}{l}\text { 2nd } \\
\text { plate }\end{array}$ & $\begin{array}{c}\text { 3rd } \\
\text { plate }\end{array}$ & $\begin{array}{l}\text { 4th } \\
\text { plate }\end{array}$ & $\begin{array}{l}\text { 5th } \\
\text { plate }\end{array}$ & $\begin{array}{c}\text { 6th } \\
\text { plate } \\
\text { (outer) }\end{array}$ \\
\hline 36.195 & 0.369 & 0.356 & 0.345 & 0.341 & 0.330 & 0.315 & 0.382 & 0.370 & 0.360 & 0.290 & 0.272 & 0.245 \\
\hline 32.385 & 0.402 & 0.397 & 0.394 & 0.379 & 0.375 & 0.361 & 0.412 & 0.404 & 0.397 & 0.349 & 0.330 & 0.312 \\
\hline 28.575 & 0.492 & 0.490 & 0.486 & 0.470 & 0.458 & 0.438 & 0.504 & 0.500 & 0.495 & 0.430 & 0.406 & 0.381 \\
\hline 24.765 & 0.587 & 0.590 & 0.581 & 0.559 & 0.544 & 0.524 & 0.601 & 0.594 & 0.588 & 0.520 & 0.491 & 0.456 \\
\hline 20.955 & 0.678 & 0.682 & 0.678 & 0.646 & 0.632 & 0.606 & 0.696 & 0.694 & 0.683 & 0.599 & 0.564 & 0.530 \\
\hline 17.145 & 0.779 & 0.782 & 0.776 & 0.739 & 0.719 & 0.698 & 0.786 & 0.783 & 0.778 & 0.680 & 0.649 & 0.603 \\
\hline 13.335 & 0.879 & 0.878 & 0.876 & 0.843 & 0.817 & 0.792 & 0.886 & 0.886 & 0.875 & 0.773 & 0.728 & 0.682 \\
\hline 9.525 & 0.994 & 0.991 & 0.985 & 0.957 & 0.926 & 0.913 & 0.992 & 0.986 & 0.978 & 0.882 & 0.844 & 0.797 \\
\hline 5.715 & 1.112 & 1.118 & 1.117 & 1.094 & 1.092 & 1.071 & 1.109 & 1.106 & 1.102 & 1.049 & 1.019 & 0.995 \\
\hline 1.905 & 1.232 & 1.236 & 1.242 & 1.243 & 1.234 & 1.232 & 1.223 & 1.223 & 1.223 & 1.220 & 1.215 & 1.211 \\
\hline-1.905 & 1.334 & 1.336 & 1.338 & 1.356 & 1.363 & 1.373 & 1.314 & 1.321 & 1.330 & 1.363 & 1.376 & 1.389 \\
\hline-5.715 & 1.412 & 1.406 & 1.415 & 1.447 & 1.462 & 1.486 & 1.385 & 1.398 & 1.406 & 1.477 & 1.498 & 1.525 \\
\hline-9.525 & 1.440 & 1.450 & 1.454 & 1.497 & 1.511 & 1.530 & 1.431 & 1.442 & 1.446 & 1.530 & 1.571 & 1.598 \\
\hline-13.335 & 1.436 & 1.446 & 1.458 & 1.500 & 1.524 & 1.537 & 1.434 & 1.437 & 1.452 & 1.529 & 1.572 & 1.614 \\
\hline-17.145 & 1.412 & 1.408 & 1.424 & 1.453 & 1.476 & 1.502 & 1.398 & 1.406 & 1.420 & 1.509 & 1.538 & 1.588 \\
\hline-20.955 & 1.331 & 1.342 & 1.349 & 1.381 & 1.389 & 1.418 & 1.332 & 1.338 & 1.345 & 1.422 & 1.461 & 1.506 \\
\hline-24.765 & 1.219 & 1.231 & 1.236 & 1.256 & 1.277 & 1.303 & 1.215 & 1.228 & 1.233 & 1.317 & 1.346 & 1.378 \\
\hline-28.575 & 1.085 & 1.084 & 1.085 & 1.111 & 1.125 & 1.141 & 1.075 & 1.079 & 1.097 & 1.165 & 1.195 & 1.224 \\
\hline-32.385 & 0.932 & 0.923 & 0.918 & 0.934 & 0.953 & 0.971 & 0.927 & 0.927 & 0.928 & 0.978 & 1.005 & 1.037 \\
\hline-36.195 & 0.878 & 0.853 & 0.844 & 0.795 & 0.793 & 0.787 & 0.899 & 0.879 & 0.864 & 0.917 & 0.920 & 0.929 \\
\hline \multirow[t]{3}{*}{ FACTF $_{k}$} & 0.8788 & 0.8515 & 0.8594 & 0.9284 & 1.0319 & 1.2280 & 0.7959 & 0.7933 & 0.8188 & 0.9431 & 1.0628 & 1.2734 \\
\hline & \multicolumn{5}{|c|}{ Azimuthal Power Peak-to-Average Ratio $\left(F_{P}\right)=$} & 1.178 & \multicolumn{5}{|c|}{ Azimuthal Power Peak-to-Average Ratio $\left(F_{P}\right)=$} & 1.071 \\
\hline & \multicolumn{5}{|c|}{ Sector Power Relative to $\mathrm{A}-\mathbf{3 0}=$} & 0.678 & \multicolumn{5}{|c|}{ Sector Power Relative to $\mathrm{A}-30=$} & 0.7471 \\
\hline
\end{tabular}


Table C-2. Power distribution for the channel A-30 fuel assembly (high heat flux fuel).

\begin{tabular}{|c|c|c|c|c|c|c|c|c|c|c|c|c|}
\hline \multirow[b]{3}{*}{$\begin{array}{l}\text { Axial Position } \\
\text { of cell center } \\
\text { (cm) }\end{array}$} & \multicolumn{6}{|c|}{ HEU, Channel A-30 (High Heat Flux Fuel Assembly) } & \multicolumn{6}{|c|}{ LEU, Channel A-30 (High Heat Flux Fuel Assembly) } \\
\hline & \multicolumn{12}{|c|}{ QAVG $_{k, n}$, Relative Power Density Distribution in Plate (Plate Average $=1$ ) } \\
\hline & $\begin{array}{c}\begin{array}{c}\text { 1st } \\
\text { plate } \\
\text { (inner) }\end{array} \\
\end{array}$ & $\begin{array}{l}\text { 2nd } \\
\text { plate }\end{array}$ & $\begin{array}{l}\text { 3rd } \\
\text { plate }\end{array}$ & $\begin{array}{l}\text { 4th } \\
\text { plate }\end{array}$ & $\begin{array}{l}5 \text { th } \\
\text { plate }\end{array}$ & $\begin{array}{c}\text { 6th } \\
\text { plate } \\
\text { (outer) }\end{array}$ & $\begin{array}{c}\text { 1st } \\
\text { plate } \\
\text { (inner) }\end{array}$ & $\begin{array}{l}\text { 2nd } \\
\text { plate }\end{array}$ & $\begin{array}{l}\text { 3rd } \\
\text { plate }\end{array}$ & $\begin{array}{l}\text { 4th } \\
\text { plate }\end{array}$ & $\begin{array}{l}\text { 5th } \\
\text { plate }\end{array}$ & $\begin{array}{c}\text { 6th } \\
\text { plate } \\
\text { (outer) }\end{array}$ \\
\hline 36.195 & 0.367 & 0.355 & 0.348 & 0.356 & 0.366 & 0.387 & 0.376 & 0.374 & 0.369 & 0.388 & 0.397 & 0.418 \\
\hline 32.385 & 0.403 & 0.401 & 0.397 & 0.423 & 0.442 & 0.471 & 0.403 & 0.408 & 0.411 & 0.445 & 0.467 & 0.498 \\
\hline 28.575 & 0.494 & 0.492 & 0.488 & 0.518 & 0.542 & 0.564 & 0.499 & 0.497 & 0.504 & 0.543 & 0.566 & 0.593 \\
\hline 24.765 & 0.597 & 0.595 & 0.593 & 0.622 & 0.646 & 0.669 & 0.616 & 0.616 & 0.616 & 0.663 & 0.678 & 0.707 \\
\hline 20.955 & 0.697 & 0.694 & 0.691 & 0.722 & 0.733 & 0.767 & 0.738 & 0.742 & 0.736 & 0.781 & 0.786 & 0.817 \\
\hline 17.145 & 0.802 & 0.790 & 0.785 & 0.821 & 0.840 & 0.861 & 0.846 & 0.844 & 0.839 & 0.880 & 0.890 & 0.909 \\
\hline 13.335 & 0.911 & 0.896 & 0.888 & 0.925 & 0.949 & 0.960 & 0.948 & 0.948 & 0.942 & 0.982 & 0.981 & 0.996 \\
\hline 9.525 & 1.003 & 1.005 & 1.000 & 1.036 & 1.031 & 1.039 & 1.059 & 1.050 & 1.035 & 1.067 & 1.067 & 1.059 \\
\hline 5.715 & 1.122 & 1.124 & 1.119 & 1.126 & 1.129 & 1.128 & 1.172 & 1.162 & 1.153 & 1.166 & 1.154 & 1.139 \\
\hline 1.905 & 1.235 & 1.239 & 1.238 & 1.221 & 1.210 & 1.208 & 1.272 & 1.267 & 1.260 & 1.250 & 1.232 & 1.215 \\
\hline-1.905 & 1.310 & 1.316 & 1.315 & 1.309 & 1.292 & 1.258 & 1.349 & 1.346 & 1.343 & 1.305 & 1.288 & 1.259 \\
\hline-5.715 & 1.381 & 1.390 & 1.388 & 1.362 & 1.340 & 1.289 & 1.406 & 1.406 & 1.398 & 1.348 & 1.336 & 1.302 \\
\hline-9.525 & 1.418 & 1.428 & 1.425 & 1.395 & 1.353 & 1.305 & 1.425 & 1.435 & 1.431 & 1.376 & 1.349 & 1.316 \\
\hline-13.335 & 1.413 & 1.424 & 1.426 & 1.397 & 1.375 & 1.328 & 1.434 & 1.427 & 1.425 & 1.373 & 1.346 & 1.319 \\
\hline-17.145 & 1.391 & 1.396 & 1.404 & 1.368 & 1.359 & 1.328 & 1.388 & 1.392 & 1.393 & 1.336 & 1.324 & 1.302 \\
\hline-20.955 & 1.340 & 1.347 & 1.354 & 1.313 & 1.302 & 1.299 & 1.310 & 1.310 & 1.323 & 1.278 & 1.266 & 1.253 \\
\hline-24.765 & 1.228 & 1.234 & 1.253 & 1.224 & 1.215 & 1.219 & 1.142 & 1.146 & 1.160 & 1.159 & 1.163 & 1.159 \\
\hline-28.575 & 1.079 & 1.084 & 1.104 & 1.082 & 1.086 & 1.099 & 0.973 & 0.984 & 1.000 & 1.010 & 1.019 & 1.026 \\
\hline-32.385 & 0.931 & 0.927 & 0.932 & 0.929 & 0.938 & 0.957 & 0.835 & 0.849 & 0.857 & 0.856 & 0.880 & 0.900 \\
\hline-36.195 & 0.878 & 0.864 & 0.854 & 0.850 & 0.852 & 0.862 & 0.807 & 0.800 & 0.805 & 0.794 & 0.811 & 0.811 \\
\hline \multirow[t]{3}{*}{ FACTF $_{k}$} & 0.8523 & 0.8315 & 0.8403 & 0.9890 & 1.0642 & 1.1859 & 0.8375 & 0.8125 & 0.8243 & 0.9781 & 1.0699 & 1.2135 \\
\hline & \multicolumn{5}{|c|}{ Azimuthal Power Peak-to-Average Ratio $\left(F_{\mathrm{P}}\right)=$} & 1.087 & \multicolumn{5}{|c|}{ Azimuthal Power Peak-to-Average Ratio $\left(F_{P}\right)=$} & 1.091 \\
\hline & \multicolumn{5}{|c|}{ Sector Power Relative to $\mathrm{A}-\mathbf{3 0}=$} & 1.000 & \multicolumn{5}{|c|}{ Sector Power Relative to $\mathrm{A}-30=$} & 1.000 \\
\hline
\end{tabular}


Table C-3. Power distribution for the channel H-1 fuel assembly (high power fuel).

\begin{tabular}{|c|c|c|c|c|c|c|c|c|c|c|c|c|}
\hline \multirow[b]{3}{*}{$\begin{array}{c}\text { Axial } \\
\text { position of } \\
\text { cell center } \\
(\mathrm{cm}) \\
\end{array}$} & \multicolumn{6}{|c|}{ HEU, Channel H-1 (High Power Fuel Assembly) } & \multicolumn{6}{|c|}{ LEU, Channel H-1 (High Power Fuel Assembly) } \\
\hline & \multicolumn{12}{|c|}{ QAVG $_{k, n}$, Relative Power Density Distribution in Plate (Plate Average = 1) } \\
\hline & $\begin{array}{c}\text { 1st } \\
\text { plate } \\
\text { (inner) }\end{array}$ & $\begin{array}{l}\text { 2nd } \\
\text { plate }\end{array}$ & $\begin{array}{l}\text { 3rd } \\
\text { plate }\end{array}$ & $\begin{array}{l}\text { 4th } \\
\text { plate }\end{array}$ & $\begin{array}{l}5^{\text {th }} \\
\text { plate }\end{array}$ & $\begin{array}{c}\text { 6th } \\
\text { plate } \\
\text { (outer) }\end{array}$ & $\begin{array}{c}\text { 1st } \\
\text { plate } \\
\text { (inner) }\end{array}$ & $\begin{array}{l}\text { 2nd } \\
\text { plate }\end{array}$ & $\begin{array}{l}\text { 3rd } \\
\text { plate }\end{array}$ & $\begin{array}{l}\text { 4th } \\
\text { plate }\end{array}$ & $\begin{array}{l}\text { 5th } \\
\text { plate }\end{array}$ & $\begin{array}{c}\text { 6th } \\
\text { plate } \\
\text { (outer) }\end{array}$ \\
\hline 36.195 & 0.500 & 0.494 & 0.488 & 0.481 & 0.490 & 0.514 & 0.550 & 0.544 & 0.545 & 0.526 & 0.540 & 0.543 \\
\hline 32.385 & 0.544 & 0.545 & 0.544 & 0.542 & 0.559 & 0.594 & 0.585 & 0.583 & 0.590 & 0.579 & 0.606 & 0.615 \\
\hline 28.575 & 0.645 & 0.648 & 0.649 & 0.642 & 0.658 & 0.686 & 0.686 & 0.686 & 0.688 & 0.686 & 0.703 & 0.718 \\
\hline 24.765 & 0.750 & 0.753 & 0.753 & 0.752 & 0.767 & 0.794 & 0.789 & 0.789 & 0.789 & 0.793 & 0.808 & 0.819 \\
\hline 20.955 & 0.836 & 0.830 & 0.845 & 0.838 & 0.859 & 0.886 & 0.863 & 0.858 & 0.867 & 0.863 & 0.893 & 0.888 \\
\hline 17.145 & 0.904 & 0.912 & 0.909 & 0.923 & 0.927 & 0.937 & 0.933 & 0.917 & 0.929 & 0.929 & 0.935 & 0.937 \\
\hline 13.335 & 0.986 & 0.994 & 0.987 & 1.002 & 1.002 & 1.014 & 1.002 & 0.985 & 1.002 & 1.000 & 1.007 & 1.004 \\
\hline 9.525 & 1.050 & 1.040 & 1.061 & 1.064 & 1.052 & 1.054 & 1.037 & 1.043 & 1.031 & 1.051 & 1.059 & 1.047 \\
\hline 5.715 & 1.104 & 1.106 & 1.110 & 1.128 & 1.113 & 1.096 & 1.088 & 1.098 & 1.096 & 1.117 & 1.100 & 1.087 \\
\hline 1.905 & 1.153 & 1.169 & 1.154 & 1.179 & 1.166 & 1.127 & 1.141 & 1.153 & 1.143 & 1.170 & 1.131 & 1.121 \\
\hline-1.905 & 1.185 & 1.170 & 1.195 & 1.180 & 1.199 & 1.146 & 1.169 & 1.180 & 1.171 & 1.205 & 1.161 & 1.156 \\
\hline-5.715 & 1.221 & 1.203 & 1.211 & 1.210 & 1.212 & 1.172 & 1.196 & 1.207 & 1.199 & 1.207 & 1.179 & 1.167 \\
\hline-9.525 & 1.232 & 1.223 & 1.206 & 1.232 & 1.207 & 1.187 & 1.207 & 1.220 & 1.209 & 1.192 & 1.196 & 1.179 \\
\hline-13.335 & 1.261 & 1.250 & 1.236 & 1.232 & 1.211 & 1.199 & 1.230 & 1.222 & 1.231 & 1.227 & 1.208 & 1.174 \\
\hline-17.145 & 1.256 & 1.251 & 1.246 & 1.239 & 1.222 & 1.201 & 1.221 & 1.214 & 1.225 & 1.229 & 1.217 & 1.181 \\
\hline-20.955 & 1.242 & 1.230 & 1.227 & 1.244 & 1.226 & 1.192 & 1.194 & 1.206 & 1.203 & 1.197 & 1.210 & 1.154 \\
\hline-24.765 & 1.180 & 1.199 & 1.203 & 1.181 & 1.180 & 1.180 & 1.153 & 1.170 & 1.170 & 1.153 & 1.166 & 1.145 \\
\hline-28.575 & 1.076 & 1.097 & 1.100 & 1.073 & 1.074 & 1.093 & 1.054 & 1.067 & 1.069 & 1.046 & 1.062 & 1.069 \\
\hline-32.385 & 0.964 & 0.975 & 0.973 & 0.970 & 0.985 & 1.017 & 0.968 & 0.948 & 0.946 & 0.948 & 0.951 & 1.049 \\
\hline-36.195 & 0.908 & 0.911 & 0.902 & 0.887 & 0.891 & 0.910 & 0.935 & 0.908 & 0.895 & 0.883 & 0.869 & 0.946 \\
\hline \multirow[t]{3}{*}{ FACTF $_{k}$} & 0.9136 & 0.8839 & 0.8984 & 0.9938 & 1.0430 & 1.1174 & 0.8917 & 0.8658 & 0.8814 & 0.9829 & 1.0391 & 1.1561 \\
\hline & \multicolumn{5}{|c|}{ Azimuthal Power Peak-to-Average Ratio $\left(F_{P}\right)=$} & 1.062 & \multicolumn{5}{|c|}{ Azimuthal Power Peak-to-Average Ratio $\left(\mathrm{F}_{\mathrm{P}}\right)=$} & 1.069 \\
\hline & \multicolumn{5}{|c|}{ Sector Power Relative to $\mathrm{A}-\mathbf{3 0}=$} & 1.040 & \multicolumn{5}{|c|}{ Sector Power Relative to $\mathrm{A}-30=$} & 1.057 \\
\hline
\end{tabular}


Table C-4. Power distribution for the channel F-346 fuel assembly (high burnup fuel).

\begin{tabular}{|c|c|c|c|c|c|c|c|c|c|c|c|c|}
\hline \multirow[b]{3}{*}{$\begin{array}{l}\text { Axial Position } \\
\text { of cell center } \\
\text { (cm) }\end{array}$} & \multicolumn{6}{|c|}{ HEU, Channel F-346 (High Burnup Fuel Assembly) } & \multicolumn{6}{|c|}{ LEU, Channel F-346 (High Burnup Fuel Assembly) } \\
\hline & \multicolumn{12}{|c|}{ QAVG $_{k, n}$, Relative Power Density Distribution in Plate (Plate Average $=1$ ) } \\
\hline & $\begin{array}{c}\begin{array}{c}\text { 1st } \\
\text { plate } \\
\text { (inner) }\end{array} \\
\end{array}$ & $\begin{array}{l}\text { 2nd } \\
\text { plate }\end{array}$ & $\begin{array}{l}\text { 3rd } \\
\text { plate }\end{array}$ & $\begin{array}{l}\text { 4th } \\
\text { plate }\end{array}$ & $\begin{array}{l}5 \text { th } \\
\text { plate }\end{array}$ & $\begin{array}{c}\text { 6th } \\
\text { plate } \\
\text { (outer) }\end{array}$ & $\begin{array}{c}\text { 1st } \\
\text { plate } \\
\text { (inner) }\end{array}$ & $\begin{array}{l}\text { 2nd } \\
\text { plate }\end{array}$ & $\begin{array}{l}\text { 3rd } \\
\text { plate }\end{array}$ & $\begin{array}{l}\text { 4th } \\
\text { plate }\end{array}$ & $\begin{array}{l}\text { 5th } \\
\text { plate }\end{array}$ & $\begin{array}{c}\text { 6th } \\
\text { plate } \\
\text { (outer) }\end{array}$ \\
\hline 36.195 & 0.353 & 0.352 & 0.336 & 0.283 & 0.272 & 0.260 & 0.358 & 0.357 & 0.350 & 0.282 & 0.270 & 0.263 \\
\hline 32.385 & 0.421 & 0.422 & 0.406 & 0.354 & 0.349 & 0.339 & 0.416 & 0.424 & 0.417 & 0.352 & 0.345 & 0.339 \\
\hline 28.575 & 0.504 & 0.512 & 0.493 & 0.432 & 0.420 & 0.410 & 0.509 & 0.506 & 0.493 & 0.423 & 0.408 & 0.398 \\
\hline 24.765 & 0.609 & 0.610 & 0.594 & 0.520 & 0.507 & 0.482 & 0.609 & 0.594 & 0.582 & 0.508 & 0.481 & 0.468 \\
\hline 20.955 & 0.699 & 0.687 & 0.689 & 0.601 & 0.570 & 0.540 & 0.669 & 0.686 & 0.666 & 0.565 & 0.542 & 0.531 \\
\hline 17.145 & 0.775 & 0.767 & 0.763 & 0.671 & 0.637 & 0.593 & 0.744 & 0.764 & 0.748 & 0.644 & 0.609 & 0.589 \\
\hline 13.335 & 0.874 & 0.860 & 0.855 & 0.756 & 0.703 & 0.665 & 0.835 & 0.855 & 0.841 & 0.724 & 0.691 & 0.662 \\
\hline 9.525 & 0.928 & 0.945 & 0.942 & 0.820 & 0.764 & 0.734 & 0.957 & 0.919 & 0.947 & 0.819 & 0.769 & 0.738 \\
\hline 5.715 & 1.044 & 1.042 & 1.052 & 0.953 & 0.921 & 0.902 & 1.083 & 1.031 & 1.063 & 0.952 & 0.954 & 0.915 \\
\hline 1.905 & 1.178 & 1.161 & 1.170 & 1.122 & 1.121 & 1.123 & 1.209 & 1.150 & 1.176 & 1.110 & 1.179 & 1.139 \\
\hline-1.905 & 1.273 & 1.251 & 1.222 & 1.257 & 1.272 & 1.239 & 1.291 & 1.272 & 1.339 & 1.290 & 1.274 & 1.287 \\
\hline-5.715 & 1.333 & 1.333 & 1.346 & 1.404 & 1.401 & 1.398 & 1.373 & 1.347 & 1.387 & 1.433 & 1.419 & 1.448 \\
\hline-9.525 & 1.318 & 1.352 & 1.433 & 1.487 & 1.459 & 1.499 & 1.408 & 1.381 & 1.363 & 1.525 & 1.520 & 1.548 \\
\hline-13.335 & 1.376 & 1.399 & 1.388 & 1.547 & 1.536 & 1.533 & 1.401 & 1.440 & 1.414 & 1.538 & 1.541 & 1.578 \\
\hline-17.145 & 1.381 & 1.401 & 1.389 & 1.522 & 1.535 & 1.527 & 1.392 & 1.422 & 1.413 & 1.533 & 1.537 & 1.573 \\
\hline-20.955 & 1.386 & 1.374 & 1.396 & 1.418 & 1.537 & 1.542 & 1.345 & 1.355 & 1.368 & 1.484 & 1.537 & 1.560 \\
\hline-24.765 & 1.346 & 1.327 & 1.317 & 1.390 & 1.454 & 1.480 & 1.268 & 1.322 & 1.314 & 1.407 & 1.440 & 1.486 \\
\hline-28.575 & 1.213 & 1.204 & 1.188 & 1.274 & 1.319 & 1.356 & 1.140 & 1.185 & 1.171 & 1.267 & 1.290 & 1.341 \\
\hline-32.385 & 1.069 & 1.078 & 1.091 & 1.188 & 1.209 & 1.294 & 1.051 & 1.055 & 1.038 & 1.147 & 1.181 & 1.163 \\
\hline-36.195 & 0.921 & 0.924 & 0.931 & 1.001 & 1.015 & 1.085 & 0.941 & 0.933 & 0.910 & 0.996 & 1.012 & 0.972 \\
\hline \multirow[t]{3}{*}{ FACTF $_{k}$} & 0.8534 & 0.8293 & 0.8636 & 1.0002 & 1.0658 & 1.1624 & 0.8390 & 0.8062 & 0.8388 & 0.9990 & 1.0726 & 1.1892 \\
\hline & \multicolumn{5}{|c|}{ Azimuthal Power Peak-to-Average Ratio $\left(F_{\mathrm{P}}\right)=$} & 1.058 & \multicolumn{5}{|c|}{ Azimuthal Power Peak-to-Average Ratio $\left(F_{P}\right)=$} & 1.069 \\
\hline & \multicolumn{5}{|c|}{ Sector Power Relative to $\mathrm{A}-\mathbf{3 0}=$} & 0.432 & \multicolumn{5}{|c|}{ Sector Power Relative to $\mathrm{A}-30=$} & 0.440 \\
\hline
\end{tabular}




\section{Hot Channel Factor Tables}

Table D-1. Hot channel factors for channel C-259 (HEU) and C-319 (LEU) fuel assemblies (fresh fuel).

\begin{tabular}{|c|c|c|c|c|c|c|c|c|c|c|c|}
\hline Uncertainty & $\begin{array}{c}\text { Type of } \\
\text { tolerance }\end{array}$ & $\begin{array}{c}\text { Effect on } \\
\text { bulk } \Delta \mathrm{T} \\
\text { (fraction) }\end{array}$ & $\begin{array}{r}\text { Toler } \\
\text { unce } \\
\text { (fra }\end{array}$ & $\begin{array}{l}\text { ce or } \\
\text { ainty } \\
\text { ion) }\end{array}$ & $\begin{array}{r}\text { Hea } \\
F\end{array}$ & flux, & $\begin{array}{c}\text { Heat } \\
\text { transfer } \\
\text { coefficient, } \\
F_{h}\end{array}$ & $\begin{array}{r}\mathrm{Ch} \\
\text { temp } \\
r \\
\mathrm{r}\end{array}$ & anel & $\begin{array}{r}\mathrm{Fi} \\
\text { tempe } \\
\mathrm{ri} \\
\mathrm{F}\end{array}$ & $\begin{array}{l}n \\
\text { ature } \\
\text { n }\end{array}$ \\
\hline${ }^{235} \mathrm{U}$ homogeneity & \multirow{5}{*}{ Random } & & \multicolumn{2}{|c|}{0.20} & \multicolumn{2}{|c|}{1.20} & & & & \multicolumn{2}{|c|}{1.20} \\
\hline${ }^{235} \mathrm{U}$ loading per plate & & 0.50 & \multicolumn{2}{|c|}{0.02} & \multicolumn{2}{|c|}{1.02} & & \multicolumn{2}{|c|}{1.01} & \multicolumn{2}{|c|}{1.02} \\
\hline Power density & & 0.50 & \multicolumn{2}{|c|}{0.19} & \multicolumn{2}{|c|}{1.19} & & \multicolumn{2}{|c|}{1.10} & \multicolumn{2}{|c|}{1.19} \\
\hline Plate spacing (HEU/LEU) & & 1.00 & 1.11 & 1.11 & & & & 1.20 & 1.20 & 1.04 & 1.04 \\
\hline Flow distribution & & 1.00 & \multicolumn{2}{|c|}{1.10} & & & & \multicolumn{2}{|c|}{1.10} & \multicolumn{2}{|c|}{1.10} \\
\hline \multicolumn{5}{|c|}{ Random errors combined (HEU/LEU) } & \multicolumn{2}{|c|}{1.28} & & 1.24 & 1.24 & 1.30 & 1.30 \\
\hline Heat transfer Coefficient & \multirow{2}{*}{ Systematic } & & \multicolumn{2}{|c|}{1.15} & & & 1.15 & & & & \\
\hline Hot stripe (HEU/LEU) & & & 1.18 & 1.07 & 1.18 & 1.07 & & 1.18 & 1.07 & 1.18 & 1.07 \\
\hline \multicolumn{5}{|c|}{ HCF, product of random errors and systematic errors (HEU/LEU) } & 1.51 & 1.37 & 1.15 & 1.46 & 1.33 & 1.53 & 1.39 \\
\hline
\end{tabular}

Table D-2. Hot channel factors for channel A-30 fuel assembly (high heat flux fuel).

\begin{tabular}{|c|c|c|c|c|c|c|c|c|c|c|c|}
\hline Uncertainty & $\begin{array}{c}\text { Type of } \\
\text { tolerance }\end{array}$ & $\begin{array}{c}\text { Effect on } \\
\text { bulk } \Delta \mathrm{T} \\
\text { (fraction) }\end{array}$ & $\begin{array}{r}\text { Toler } \\
\text { unce } \\
\text { (fra }\end{array}$ & $\begin{array}{l}\text { ere or } \\
\text { ainty } \\
\text { ion) }\end{array}$ & Hea & flux, & $\begin{array}{c}\text { Heat } \\
\text { transfer } \\
\text { coefficient, } \\
\mathrm{F}_{\mathrm{h}}\end{array}$ & $\begin{array}{r}\mathrm{Ch} \\
\text { temp } \\
r \\
\mathrm{r}\end{array}$ & $\begin{array}{l}\text { inel } \\
\text { rature } \\
\text { e, } \\
\text { lk }\end{array}$ & $\begin{array}{r}\mathrm{F} \\
\text { temp } \\
\mathrm{ri} \\
\mathrm{F}\end{array}$ & $\begin{array}{l}\text { n } \\
\text { ature } \\
\text { m }\end{array}$ \\
\hline${ }^{235} \mathrm{U}$ loading per plate & \multirow[b]{2}{*}{ Random } & 0.50 & \multicolumn{2}{|c|}{0.02} & \multicolumn{2}{|c|}{1.02} & & \multicolumn{2}{|c|}{1.01} & \multicolumn{2}{|c|}{1.02} \\
\hline Power density & & 0.50 & \multicolumn{2}{|c|}{0.19} & \multicolumn{2}{|c|}{1.19} & & \multicolumn{2}{|c|}{1.10} & \multicolumn{2}{|c|}{1.19} \\
\hline \multicolumn{5}{|c|}{ Random errors combined (HEU/LEU) } & \multicolumn{2}{|c|}{1.28} & & 1.25 & 1.25 & 1.30 & 1.30 \\
\hline Heat transfer Coefficient & \multirow{2}{*}{ Systematic } & & \multicolumn{2}{|c|}{1.15} & & & 1.15 & & & & \\
\hline Hot stripe (HEU/LEU) & & & 1.09 & 1.09 & 1.09 & 1.09 & & 1.09 & 1.09 & 1.09 & 1.09 \\
\hline \multicolumn{5}{|c|}{ HCF, product of random errors and systematic errors (HEU/LEU) } & 1.39 & 1.40 & 1.15 & 1.36 & 1.36 & 1.41 & 1.42 \\
\hline
\end{tabular}


Table D-3. Hot channel factors for channel H-1 fuel assembly (high power fuel).

\begin{tabular}{|c|c|c|c|c|c|c|c|c|c|c|c|}
\hline Uncertainty & $\begin{array}{l}\text { Type of } \\
\text { tolerance }\end{array}$ & $\begin{array}{c}\text { Effect on } \\
\text { bulk } \Delta \mathrm{T} \\
\text { (fraction) }\end{array}$ & $\begin{array}{r}\text { Toler } \\
\text { unce } \\
\text { (fra }\end{array}$ & $\begin{array}{l}\text { ace or } \\
\text { ainty } \\
\text { ion) }\end{array}$ & $\begin{array}{r}\text { Hea } \\
F\end{array}$ & & $\begin{array}{c}\text { Heat } \\
\text { transfer } \\
\text { coefficient, } \\
\mathrm{F}_{\mathrm{h}}\end{array}$ & $\begin{array}{r}\mathrm{Ch} \\
\text { temp } \\
r \\
\mathrm{r}\end{array}$ & $\begin{array}{l}\text { nel } \\
\text { ature } \\
\text { lk }\end{array}$ & $\begin{array}{r}\mathrm{F} \\
\text { temp } \\
\mathrm{r} \\
\mathrm{F}\end{array}$ & $\begin{array}{l}\text { n } \\
\text { ature } \\
\text { n }\end{array}$ \\
\hline${ }^{235} \mathrm{U}$ loading per plate & \multirow[b]{2}{*}{ Random } & 0.50 & \multicolumn{2}{|c|}{0.02} & \multicolumn{2}{|c|}{1.02} & & \multicolumn{2}{|c|}{1.01} & \multicolumn{2}{|c|}{1.02} \\
\hline Power density & & 0.50 & \multicolumn{2}{|c|}{0.19} & \multicolumn{2}{|c|}{1.19} & & \multicolumn{2}{|c|}{1.10} & \multicolumn{2}{|c|}{1.19} \\
\hline \multicolumn{5}{|c|}{ Random errors combined (HEU/LEU) } & \multicolumn{2}{|c|}{1.28} & & 1.25 & 1.25 & 1.30 & 1.30 \\
\hline Heat transfer Coefficient & \multirow{2}{*}{ Systematic } & & \multicolumn{2}{|c|}{1.15} & & & 1.15 & & & & \\
\hline Hot stripe (HEU/LEU) & & & 1.06 & 1.07 & 1.06 & 1.07 & & 1.06 & 1.07 & 1.06 & 1.07 \\
\hline \multicolumn{5}{|c|}{ HCF, product of random errors and systematic errors (HEU/LEU) } & 1.36 & 1.37 & 1.15 & 1.33 & 1.34 & 1.38 & 1.39 \\
\hline
\end{tabular}

Table D-4. Hot channel factors for channel F-314 fuel assembly (high burnup fuel).

\begin{tabular}{|c|c|c|c|c|c|c|c|c|c|c|c|}
\hline Uncertainty & $\begin{array}{c}\text { Type of } \\
\text { tolerance }\end{array}$ & $\begin{array}{c}\text { Effect on } \\
\text { bulk } \Delta \mathrm{T} \\
\text { (fraction) }\end{array}$ & $\begin{array}{r}\text { Toler } \\
\text { unce } \\
\text { (fra } \\
\end{array}$ & $\begin{array}{l}\text { ece or } \\
\text { ainty } \\
\text { ion) }\end{array}$ & $\begin{array}{r}\text { Hea } \\
\mathrm{F}\end{array}$ & flux, & $\begin{array}{c}\text { Heat } \\
\text { transfer } \\
\text { coefficient, } \\
\mathrm{F}_{\mathrm{h}} \\
\end{array}$ & $\begin{array}{r}\mathrm{Ch} \\
\text { temp } \\
r \\
\mathrm{r}\end{array}$ & $\begin{array}{l}\text { inel } \\
\text { rature } \\
\text { e, } \\
\text { lk }\end{array}$ & $\begin{array}{r}\mathrm{F} \\
\text { temp } \\
\mathrm{ri} \\
\mathrm{F}\end{array}$ & $\begin{array}{l}\mathrm{m} \\
\text { rature } \\
\mathrm{e}, \\
\mathrm{Im}\end{array}$ \\
\hline${ }^{235} \mathrm{U}$ loading per plate & \multirow[b]{2}{*}{ Random } & 0.50 & \multicolumn{2}{|c|}{0.02} & \multicolumn{2}{|c|}{1.02} & & \multicolumn{2}{|c|}{1.01} & \multicolumn{2}{|c|}{1.02} \\
\hline Power density & & 0.50 & \multicolumn{2}{|c|}{0.19} & \multicolumn{2}{|c|}{1.19} & & \multicolumn{2}{|c|}{1.10} & \multicolumn{2}{|c|}{1.19} \\
\hline \multicolumn{5}{|c|}{ Random errors combined (HEU/LEU) } & \multicolumn{2}{|c|}{1.28} & & 1.25 & 1.25 & 1.30 & 1.30 \\
\hline Heat transfer Coefficient & \multirow{2}{*}{ Systematic } & & \multicolumn{2}{|c|}{1.15} & & & 1.15 & & & & \\
\hline Hot stripe (HEU/LEU) & & & 1.06 & 1.07 & 1.06 & 1.07 & & 1.06 & 1.07 & 1.06 & 1.07 \\
\hline \multicolumn{5}{|c|}{ HCF, product of random errors and systematic errors (HEU/LEU) } & 1.35 & 1.37 & 1.15 & 1.33 & 1.34 & 1.38 & 1.39 \\
\hline
\end{tabular}




\section{E. Evaluation of the Uncertainty on Flow Distribution}

A series of coolant speed measurements in a BR2 fuel assembly is presented in Ref. [15]. Table E-1 shows the speed measured in each channel.

Table E-1. Measured coolant speed in various channels of a BR2 fuel assembly.

\begin{tabular}{|c|crr|}
\hline Channel & \multicolumn{3}{|c|}{ Measured Coolant Speed $(\mathrm{m} / \mathrm{s})$} \\
\hline 1 & 9.75 & 10.40 & 9.99 \\
& 10.20 & 10.00 & 10.40 \\
\hline 2 & 10.20 & 10.17 & 10.50 \\
& 9.88 & 9.61 & 9.62 \\
\hline 3 & 10.13 & 10.60 & 11.53 \\
& 10.50 & 10.50 & 10.69 \\
\hline 4 & 10.48 & 10.72 & 10.60 \\
& 10.91 & 10.40 & 10.78 \\
\hline 5 & 10.67 & 10.90 & 10.89 \\
& 10.70 & 10.63 & 10.18 \\
\hline 6 & 10.47 & 10.60 & 10.40 \\
& 10.05 & & 10.71 \\
\hline 7 & 10.70 & 10.86 & 10.80 \\
& 10.80 & 10.40 & 9.80 \\
\hline
\end{tabular}

For each channel, an average and standard deviation is calculated from the values in the above table. The largest relative error of $4.3 \%$ (standard deviation/average) is obtained for channel 3. The HCF component that reflects uncertainty in flow distribution is assumed to be twice the largest relative error. Therefore, an uncertainty of 1.09 is assumed in the evaluation of the HCFs. 


\section{F. PLTEMP Result Tables}

Table F-1. T-H criteria and fuel temperature results for HEU fuel.

\begin{tabular}{|c|c|c|c|c|c|c|c|c|c|c|c|c|c|c|}
\hline \multicolumn{2}{|c|}{ HEU } & \multicolumn{4}{|c|}{ High Heat Flux (A-30) } & \multicolumn{3}{|c|}{ High Power $(\mathrm{H}-1)$} & \multicolumn{3}{|c|}{ High Burnup (F-314) } & \multicolumn{3}{|c|}{ Fresh Fuel (C-259) } \\
\hline $\begin{array}{c}\text { Flow / } \\
\mathrm{dP}, \mathrm{MPa}\end{array}$ & $\begin{array}{l}\text { Limiting } \\
\text { Condition }\end{array}$ & $\begin{array}{l}\text { Heat } \\
\text { Flux, } \\
\mathrm{W} / \mathrm{cm}^{2}\end{array}$ & $\begin{array}{c}\text { Sector } \\
\text { Power, } \\
\text { MW }\end{array}$ & $\begin{array}{c}\text { Wall } \\
\text { Temp., } \\
{ }^{\circ} \mathrm{C}\end{array}$ & $\begin{array}{c}\text { Fuel } \\
\text { Temp., } \\
{ }^{\circ} \mathrm{C}\end{array}$ & $\begin{array}{c}\text { Sector } \\
\text { Power, } \\
\text { MW }\end{array}$ & Margin & $\begin{array}{c}\text { Fuel } \\
\text { Temp., } \\
{ }^{\circ} \mathrm{C}\end{array}$ & $\begin{array}{c}\text { Sector } \\
\text { Power, } \\
\text { MW }\end{array}$ & Margin & $\begin{array}{c}\text { Fuel } \\
\text { Temp., } \\
{ }^{\circ} \mathrm{C}\end{array}$ & $\begin{array}{c}\text { Sector } \\
\text { Power, } \\
\text { MW }\end{array}$ & Margin & $\begin{array}{c}\text { Fuel } \\
\text { Temp., } \\
{ }^{\circ} \mathrm{C}\end{array}$ \\
\hline \multirow{4}{*}{$\begin{array}{c}1 \% / \\
8.00 \mathrm{E}-05\end{array}$} & ONBR=1 & 13.8 & 0.0246 & 190.7 & 191.6 & 0.0256 & 1.02 & 189.2 & 0.0106 & 2.00 & 116.0 & 0.0167 & 1.28 & 158.7 \\
\hline & $\mathrm{FDNBR}=1$ & 14.3 & 0.0255 & 195.3 & 196.3 & 0.0265 & 1.02 & 193.7 & 0.0110 & 1.98 & 118.5 & 0.0173 & 1.28 & 162.4 \\
\hline & $\mathrm{CHFR}=1$ & \multicolumn{13}{|c|}{ NA } \\
\hline & OFIR=1 & 18.1 & 0.0321 & 229.0 & 230.2 & 0.0334 & 0.99 & 227.5 & 0.0139 & 2.33 & 136.6 & 0.0218 & 1.38 & 189.6 \\
\hline \multirow{4}{*}{$\begin{array}{c}20 \% / \\
1.11 \mathrm{E}-02\end{array}$} & ONBR=1 & 168.5 & 0.3370 & 193.7 & 208.6 & 0.3504 & 1.05 & 201.9 & 0.1454 & 1.92 & 128.6 & 0.2284 & 1.15 & 180.2 \\
\hline & FDNBR=1 & 182.0 & 0.3642 & 204.2 & 220.3 & 0.3787 & 1.05 & 213.1 & 0.1572 & 1.88 & 135.1 & 0.2468 & 1.14 & 190.0 \\
\hline & $\mathrm{CHFR}=1$ & 526.1 & 1.0662 & 452.7 & 500.6 & 1.1087 & 1.04 & 479.1 & 0.4601 & 2.27 & 283.5 & 0.7227 & 1.24 & 423.3 \\
\hline & OFIR=1 & 309.1 & 0.6215 & 299.9 & 327.5 & 0.6462 & 1.03 & 315.0 & 0.2682 & 2.37 & 193.2 & 0.4212 & 1.30 & 277.4 \\
\hline \multirow{6}{*}{$\begin{array}{c}100 \% / \\
2.10 E-01\end{array}$} & $Q^{\prime \prime}=470$ & 470.0 & 0.9712 & 163.6 & 206.0 & 1.0099 & 1.13 & 198.9 & 0.4191 & 2.10 & 129.5 & 0.6583 & 1.14 & 164.7 \\
\hline & $Q^{\prime \prime}=600$ & 600.0 & 1.2439 & 193.0 & 247.5 & 1.2934 & 1.13 & 238.0 & 0.5368 & 2.10 & 153.0 & 0.8431 & 1.14 & 196.0 \\
\hline & ONBR=1 & 600.3 & 1.2445 & 193.0 & 247.6 & 1.2941 & 1.08 & 238.4 & 0.5370 & 1.89 & 153.1 & 0.8435 & 1.14 & 196.1 \\
\hline & FDNBR=1 & 672.5 & 1.3962 & 208.7 & 270.1 & 1.4518 & 1.08 & 259.7 & 0.6025 & 1.85 & 165.9 & 0.9463 & 1.14 & 213.0 \\
\hline & $\mathrm{CHFR}=1$ & 1177.9 & 2.4623 & 316.5 & 425.7 & 2.5604 & 1.06 & 408.2 & 1.0626 & 2.26 & 248.9 & 1.6689 & 1.25 & 326.6 \\
\hline & OFIR=1 & 1374.7 & 2.8809 & 356.9 & 485.1 & 2.9957 & 1.03 & 465.4 & 1.2432 & 2.38 & 284.7 & 1.9527 & 1.37 & 371.0 \\
\hline \multirow{4}{*}{$\begin{array}{c}161 \% / \\
5.15 E-01\end{array}$} & ONBR=1 & 832.5 & 1.7386 & 186.2 & 262.8 & 1.8079 & 1.07 & 255.7 & 0.7503 & 1.87 & 163.1 & 1.1784 & 1.15 & 198.8 \\
\hline & FDNBR=1 & 950.3 & 1.9881 & 203.9 & 291.7 & 2.0673 & 1.07 & 283.9 & 0.8579 & 1.83 & 179.7 & 1.3475 & 1.14 & 219.3 \\
\hline & $\mathrm{CHFR}=1$ & 1543.0 & 3.2459 & 291.9 & 436.3 & 3.3752 & 1.05 & 423.9 & 1.4007 & 2.23 & 256.4 & 2.2001 & 1.25 & 318.9 \\
\hline & OFIR=1 & 1962.6 & 4.1422 & 352.0 & 537.1 & 4.3072 & 1.03 & 522.3 & 1.7875 & 2.38 & 316.7 & 2.8076 & 1.37 & 389.7 \\
\hline
\end{tabular}


Table F-2. T-H criteria and fuel temperature results for LEU fuel.

\begin{tabular}{|c|c|c|c|c|c|c|c|c|c|c|c|c|c|c|}
\hline \multicolumn{2}{|c|}{ LEU } & \multicolumn{4}{|c|}{ High Heat Flux (A-30) } & \multicolumn{3}{|c|}{ High Power $(\mathrm{H}-1)$} & \multicolumn{3}{|c|}{ High Burnup (F-314) } & \multicolumn{3}{|c|}{ Fresh Fuel (C-319) } \\
\hline $\begin{array}{c}\text { Flow / } \\
\mathrm{dP}, \mathrm{MPa}\end{array}$ & $\begin{array}{l}\text { Limiting } \\
\text { Condition }\end{array}$ & $\begin{array}{l}\text { Heat } \\
\text { Flux, } \\
\text { W/cm }{ }^{2}\end{array}$ & $\begin{array}{c}\text { Sector } \\
\text { Power, } \\
\text { MW }\end{array}$ & $\begin{array}{c}\text { Wall } \\
\text { Temp., } \\
{ }^{\circ} \mathrm{C}\end{array}$ & $\begin{array}{c}\text { Fuel } \\
\text { Temp., } \\
{ }^{\circ} \mathrm{C}\end{array}$ & $\begin{array}{c}\text { Sector } \\
\text { Power, } \\
\text { MW }\end{array}$ & Margin & $\begin{array}{c}\text { Fuel } \\
\text { Temp., } \\
{ }^{\circ} \mathrm{C}\end{array}$ & $\begin{array}{c}\text { Sector } \\
\text { Power, } \\
\text { MW }\end{array}$ & Margin & $\begin{array}{c}\text { Fuel } \\
\text { Temp., } \\
{ }^{\circ} \mathrm{C}\end{array}$ & $\begin{array}{c}\text { Sector } \\
\text { Power, } \\
\text { MW }\end{array}$ & Margin & $\begin{array}{c}\text { Fuel } \\
\text { Temp., } \\
{ }^{\circ} \mathrm{C}\end{array}$ \\
\hline \multirow{4}{*}{$\begin{array}{c}1 \% / \\
8.00 E-05\end{array}$} & ONBR $=1$ & 14.1 & 0.0243 & 190.7 & 191.8 & 0.0257 & 1.01 & 191.0 & 0.0107 & 1.92 & 119.1 & 0.0182 & 1.21 & 164.9 \\
\hline & $\mathrm{FDNBR}=1$ & 14.6 & 0.0252 & 195.3 & 196.4 & 0.0266 & 1.01 & 195.5 & 0.0111 & 1.91 & 121.8 & 0.0188 & 1.22 & 168.5 \\
\hline & $\mathrm{CHFR}=1$ & \multicolumn{13}{|c|}{ NA } \\
\hline & $O F I R=1$ & 18.7 & 0.0322 & 231.3 & 232.9 & 0.0340 & 0.97 & 232.1 & 0.0142 & 2.25 & 141.6 & 0.0240 & 1.33 & 198.4 \\
\hline \multirow{4}{*}{$\begin{array}{c}20 \% / \\
1.11 \mathrm{E}-02\end{array}$} & ONBR $=1$ & 168.3 & 0.3257 & 193.7 & 211.2 & 0.3443 & 1.06 & 204.5 & 0.1433 & 1.83 & 136.0 & 0.2433 & 1.11 & 186.3 \\
\hline & $\mathrm{FDNBR}=1$ & 181.8 & 0.3519 & 204.2 & 223.1 & 0.3721 & 1.06 & 216.0 & 0.1549 & 1.80 & 143.0 & 0.2629 & 1.11 & 196.5 \\
\hline & $\mathrm{CHFR}=1$ & 528.8 & 1.0388 & 455.2 & 512.7 & 1.0984 & 1.02 & 491.7 & 0.4571 & 2.15 & 308.8 & 0.7761 & 1.23 & 441.3 \\
\hline & OFIR $=1$ & 314.2 & 0.6120 & 304.2 & 337.5 & 0.6471 & 1.00 & 324.8 & 0.2693 & 2.30 & 208.9 & 0.4572 & 1.33 & 293.4 \\
\hline \multirow{6}{*}{$\begin{array}{c}100 \% / \\
2.10 \mathrm{E}-01\end{array}$} & $Q^{\prime \prime}=470$ & 470.0 & 0.9371 & 163.7 & 214.6 & 0.9908 & 1.11 & 214.2 & 0.4123 & 2.00 & 143.7 & 0.7001 & 1.08 & 172.5 \\
\hline & $Q^{\prime \prime}=600$ & 600.0 & 1.1997 & 193.1 & 258.5 & 1.2685 & 1.12 & 258.5 & 0.5279 & 1.99 & 171.1 & 0.8963 & 1.07 & 205.6 \\
\hline & ONBR $=1$ & 600.7 & 1.2011 & 193.2 & 258.8 & 1.2700 & 1.07 & 258.7 & 0.5285 & 1.80 & 171.3 & 0.8974 & 1.10 & 205.7 \\
\hline & $\mathrm{FDNBR}=1$ & 672.9 & 1.3476 & 208.9 & 282.6 & 1.4249 & 1.07 & 282.9 & 0.5930 & 1.77 & 186.3 & 1.0068 & 1.10 & 223.6 \\
\hline & $\mathrm{CHFR}=1$ & 1197.1 & 2.414 & 320.7 & 454 & 2.5524 & 1.02 & 454.8 & 1.0622 & 2.18 & 291.5 & 1.8036 & 1.27 & 344.1 \\
\hline & OFIR=1 & 1402.3 & 2.8343 & 362.8 & 519.9 & 2.9969 & 1.00 & 521.2 & 1.2471 & 2.31 & 331.3 & 2.1176 & 1.34 & 400.1 \\
\hline \multirow{4}{*}{$\begin{array}{c}161 \% / \\
5.15 \mathrm{E}-01\end{array}$} & ONBR $=1$ & 833.8 & 1.6785 & 186.5 & 278.5 & 1.7748 & 1.06 & 283.9 & 0.7386 & 1.78 & 187.2 & 1.2541 & 1.10 & 205.5 \\
\hline & $\mathrm{FDNBR}=1$ & 951.8 & 1.9188 & 204.3 & 309.7 & 2.0288 & 1.06 & 316.0 & 0.8443 & 1.75 & 207.2 & 1.4336 & 1.10 & 232.0 \\
\hline & $\mathrm{CHFR}=1$ & 1570.3 & 3.1828 & 295.9 & 472.1 & 3.3653 & 0.99 & 482.8 & 1.4005 & 2.14 & 309.6 & 2.3780 & 1.25 & 336.3 \\
\hline & OFIR=1 & 2004.2 & 4.0747 & 358.0 & 584.5 & 4.3084 & 1.00 & 598.8 & 1.7929 & 2.32 & 379.5 & 3.0443 & 1.34 & 423.9 \\
\hline
\end{tabular}




\section{G. Model sensitivity analysis}

A sensitivity analysis was performed for the high heat flux fuel assembly in channel A-30 of the HEU core to determine the impact on $\mathrm{T}-\mathrm{H}$ margins due to changing the PLTEMP modeling method, fuel plate thermal resistance and power distribution relative to previous work described in Ref. [1] and [2]. The analysis results are summarized in Table G-1. The first section in Table G-1 shows the results obtained from repeating previous calculations given in Ref. [1] and [2]. To start, good agreement was obtained between the reported values and re-running the input files. Two additional simulations were performed with changes needed to make the models consistent with current work. The first was to correct the $\eta$ value (change from 32.5 to 24.93) in the Whittle and Forgan correlation, as described in Section 3.7, to provide a fair comparison of the OFI heat flux and that calculated for the extended Groeneveld 2006 CHF look-up table. The second was to re-define the axial meshing in the PLTEMP input file to be consistent with the meshing definition given in the PLTEMP user manual [8]. The results from file name T3 include both of these changes and are used as the basis for comparison with current analyses $\left(2^{\text {nd }}\right.$ and $3^{\text {rd }}$ sections in Table G-1).

The second section of Table G-1 shows results from repeating the above calculations (using the 3-layer plate fuel plate model) but replaces the power distribution of plate 6 , the amount of direct heating to the coolant and the thermal resistance of the fuel element with the values for the current representative core. The percent change in heat flux for each of the T-H criterion is also presented in a step-by-step manner.

The third section of Table G-1 is similar to the second section except that the 5-layer fuel plate model was used. The 5 -layer fuel plate model requires that the power distribution for each plate be specified and that the stripe method be used (described in the PLTEMP user manual). This stripe method requires discretizing the fuel plate and coolant channel in azimuthal direction to distinguish the fuelled and unfuelled regions. Because there is no azimuthal mixing of the coolant in PLTEMP, this method can produce results with increased conservatism (same amount of heat transferred to less coolant).

Finally the results from changing from the HBM to DSM for CHF can be found by comparing results of Table G-1 to the results presented in Table F-1. The CHF is reduced from $1413 \mathrm{~W} / \mathrm{cm}^{2}$ to $1178 \mathrm{~W} / \mathrm{cm}^{2}$.

Some conclusions from the results of the sensitivity analysis are as follows:

There was negligible difference $(0.3 \%)$ between the results of the 3-layer and 5-layer plate models for ONB. For each case, the ONB heat flux was found to decrease by $\sim 2.5 \%$, where $\sim 1 \%$ was due to the change in power distribution from the previous representative core and $\sim 1.5 \%$ was due to the improved methods for characterizing the thermal resistance of the fuel plate (as described in Ref. [10]).

The change in power distribution had a larger impact on OFI than CHF (-7.0\% and $-4.5 \%$, respectively) for the 3-layer fuel plate model. These values increase to $-10.4 \%$ and $-6.1 \%$, respectively, for the 5 -layer fuel plate model. 
The impact of direct heating of the coolant on the heat flux for ONB, OFI and CHF was not sensitive to the fuel plate model selection. The magnitude of the impact was larger for OFI than CHF $(6.8 \%$ versus 3.1\%). The impact on ONB was small (0.5\%).

The impact of the fuel plate's thermal resistance on the heat flux for ONB, OFI and CHF was not sensitive to the fuel plate model selection. The thermal resistance contributed for about $-1 \%$ to $-1.5 \%$ of the change in heat flux from the previous work. 
Table G-1. Sensitivity analysis for fuel assembly A-30 in HEU core.

\begin{tabular}{|c|c|c|c|c|c|c|}
\hline & & & \multicolumn{3}{|c|}{ Intermediate steps. } & Final results \\
\hline \multirow{5}{*}{1} & \multirow{5}{*}{$\begin{array}{l}\text { Repeat } \\
\text { previous work } \\
\text { described in } \\
\text { Ref. [1] and [2] }\end{array}$} & File Name & - & T1 & $\mathrm{T} 2$ & T3 \\
\hline & & TH Criterion & $\begin{array}{c}\text { Reported Value } \\
\text { in Ref. } \\
\text { [1] and [2] } \\
\text { (PLTEMP/ANL V4.11) }\end{array}$ & $\begin{array}{l}\text { Rerun previous } \\
\text { PLTEMP files } \\
\text { (PLTEMP/ANLV4.1) }\end{array}$ & $\begin{array}{l}\text { Rerun T1 with } \\
\quad \eta=24.93\end{array}$ & $\begin{array}{l}\text { Update T2 } \\
\text { meshing } \\
\text { definition. }\end{array}$ \\
\hline & & $\mathrm{OFI}\left(\mathrm{W} / \mathrm{cm}^{2}\right)$ & 1409 & 1409 & 1480.4 & 1449.4 \\
\hline & & $\mathrm{CHF}\left(\mathrm{W} / \mathrm{cm}^{2}\right)$ & $\sim 1500$ & 1506.8 & NA & 1477.5 \\
\hline & & ONB $\left(\mathrm{W} / \mathrm{cm}^{2}\right)$ & 620.1 & 620.2 & NA & 617.9 \\
\hline
\end{tabular}

\begin{tabular}{|c|c|}
\hline $\begin{array}{c}\text { Percent change in heat flux due to } \\
\text { intermediate steps. }\end{array}$ & $\begin{array}{c}\text { Change } \\
\text { from } \\
\text { previous } \\
\text { work. }\end{array}$ \\
\hline
\end{tabular}

\begin{tabular}{|c|c|c|c|c|c|c|}
\hline \multirow{5}{*}{2} & \multirow{4}{*}{$\begin{array}{l}\text { Current work. } \\
\text { IEND = } 0 \\
\text { (3-layer plate } \\
\text { model) } \\
\text { NAXDIS = } 1 \\
\text { (same power } \\
\text { shape for every } \\
\text { fuel plate) }\end{array}$} & $\begin{array}{l}\text { File Name / } \\
\text { Equation }\end{array}$ & T4 & T5 & T6a & T6b \\
\hline & & TH criterion & $\begin{array}{c}\text { Rerun T3 with } \\
\text { current power } \\
\text { distribution } \\
\text { (plate } 6 \text { in } \\
\text { Appendix C). }\end{array}$ & $\begin{array}{l}\text { Rerun T4 with } \\
\text { new values for } \\
\text { direct heating } \\
\text { of coolant } \\
\text { (Table 3) }\end{array}$ & $\begin{array}{l}\text { Rerun T5 with } \\
\text { current } \\
\text { thermal } \\
\text { resistance } \\
\text { (neglect } \\
\text { oxide) (Table } \\
1 \text { and 2) }\end{array}$ & $\begin{array}{l}\text { Rerun T5 with } \\
\text { current } \\
\text { thermal } \\
\text { resistance } \\
\text { (include oxide) } \\
\text { (Table } 1 \text { and 2) }\end{array}$ \\
\hline & & OFI (W/cm $\left.{ }^{2}\right)$ & 1347.7 & 1440.0 & 1437.2 & 1426.7 \\
\hline & & $\mathrm{CHF}\left(\mathrm{W} / \mathrm{cm}^{2}\right)$ & 1410.9 & 1554.5 & 1450.5 & 1437.2 \\
\hline & & ONB $\left(\mathrm{W} / \mathrm{cm}^{2}\right)$ & 608.3 & 610.9 & 608.7 & 601.2 \\
\hline
\end{tabular}

\begin{tabular}{|c|c|c|c|}
\hline (T4-T3)/T3 & (T5-T4)/T4 & (T6b-T5)/T5 & (T6b-T3)/T3 \\
\hline $\begin{array}{c}\text { Change due } \\
\text { to new } \\
\text { power } \\
\text { distribution }\end{array}$ & $\begin{array}{c}\text { Change } \\
\text { due to } \\
\text { direct } \\
\text { heating of } \\
\text { coolant }\end{array}$ & $\begin{array}{c}\text { Change due } \\
\text { to thermal } \\
\text { resistance in } \\
\text { fuel plate }\end{array}$ & $\begin{array}{c}\text { Change in } \\
\text { heat flux } \\
\text { from } \\
\text { previous } \\
\text { work. }\end{array}$ \\
\hline$-7.0 \%$ & $6.8 \%$ & $-0.9 \%$ & $-1.6 \%$ \\
\hline$-4.5 \%$ & $3.1 \%$ & $-1.2 \%$ & $-2.7 \%$ \\
\hline$-1.6 \%$ & $0.4 \%$ & $-1.6 \%$ & $-2.5 \%$ \\
\hline
\end{tabular}

\begin{tabular}{|c|c|c|c|c|c|c|}
\hline \multirow{5}{*}{3} & \multirow{5}{*}{$\begin{array}{l}\text { Current work. } \\
\text { IEND = } 1 \\
\text { (5-layer plate } \\
\text { model) } \\
\text { NAXDIS = } 2 \\
\text { (different } \\
\text { power shape } \\
\text { for every fuel } \\
\text { plate) }\end{array}$} & $\begin{array}{l}\text { File Name / } \\
\text { Equation }\end{array}$ & T7 & T8 & T9 & T10 \\
\hline & & TH criterion & $\begin{array}{l}\text { Rerun T4 using } \\
\text { 5-layer plate } \\
\text { model. (use } \\
\text { plate } 6 \text { power } \\
\text { distribution for } \\
\text { all plates) }\end{array}$ & $\begin{array}{l}\text { Rerun T7 using } \\
\text { correct power } \\
\text { distribution for } \\
\text { each plate. } \\
\text { (Appendix C) }\end{array}$ & $\begin{array}{c}\text { Rerun T8 with } \\
\text { new values } \\
\text { for direct } \\
\text { heating of } \\
\text { coolant } \\
\text { (Table 3) }\end{array}$ & $\begin{array}{l}\text { Rerun T9 with } \\
\text { updated fuel } \\
\text { thermal } \\
\text { resistance } \\
\text { (Table } 1 \text { and 2) }\end{array}$ \\
\hline & & OFI $\left(\mathrm{W} / \mathrm{cm}^{2}\right)$ & 1298.9 & 1298.9 & 1387.6 & 1374.7 \\
\hline & & $\mathrm{CHF}\left(\mathrm{W} / \mathrm{cm}^{2}\right)$ & 1387.0 & 1386.4 & 1429.4 & 1412.8 \\
\hline & & ONB $\left(\mathrm{W} / \mathrm{cm}^{2}\right)$ & 606.6 & 606.6 & 609.5 & 600.3 \\
\hline
\end{tabular}

\begin{tabular}{|c|c|c|c|}
\hline (T7-T3)/T3 & (T9-T8)/T8 & (T10-T9)/T9 & (T10-T3)/T3 \\
\hline $\begin{array}{c}\text { Change due } \\
\text { to fuel } \\
\text { plate stripe } \\
\text { method }\end{array}$ & $\begin{array}{c}\text { Change } \\
\text { due to } \\
\text { direct } \\
\text { heating of } \\
\text { coolant }\end{array}$ & $\begin{array}{c}\text { Change due } \\
\text { to thermal } \\
\text { resistance in } \\
\text { fuel plate }\end{array}$ & $\begin{array}{c}\text { Change in } \\
\text { heat flux } \\
\text { from } \\
\text { previous } \\
\text { work. }\end{array}$ \\
\hline$-10.4 \%$ & $6.8 \%$ & $-0.9 \%$ & $-5.2 \%$ \\
\hline$-6.1 \%$ & $3.1 \%$ & $-1.2 \%$ & $-4.4 \%$ \\
\hline$-1.8 \%$ & $0.5 \%$ & $-1.5 \%$ & $-2.8 \%$ \\
\hline
\end{tabular}


(This page intentionally left blank) 


\section{Argonne}

Nuclear Engineering Division

Argonne National Laboratory

9700 South Cass Avenue, Bldg. 208

Argonne, IL 60439-4842

www.anl.gov 